\title{
Lapurdum
}

Euskal ikerketen aldizkaria | Revue d'études basques |

Revista de estudios vascos | Basque studies review

Numéro spécial $2 \mid 2015$

Othoi çato etchera

\section{Le Dauphin itsasontziko gutuneria (1757) edo euskararen historia behetik}

\section{Manuel Padilla-Moyano}

\section{OpenEdition}

\section{Journals}

Édition électronique

URL : https://journals.openedition.org/lapurdum/2553

DOI : 10.4000/lapurdum.2553

ISSN : 1965-0655

Éditeur

IKER

Édition imprimée

Date de publication : 1 octobre 2015

Pagination : 45-77

ISBN : 978-2-9553413-1-5

ISSN : $1273-3830$

Référence électronique

Manuel Padilla-Moyano, «Le Dauphin itsasontziko gutuneria (1757) edo euskararen historia behetik», Lapurdum [Linean], Numéro spécial 2 | 2015, Sarean emana----an 25 juillet 2016, kontsultatu 02 avril 2023. URL: http://journals.openedition.org/lapurdum/2553 ; DOI: https://doi.org/10.4000/lapurdum 2553

\section{(c) (i) (2) $\Theta$}

Creative Commons - Attribution-NonCommercial-NoDerivatives 4.0 International - CC BY-NC-ND 4.0 https://creativecommons.org/licenses/by-nc-nd/4.0/ 


\title{
Le Dauphin itsasontziko gutuneria (1757) edo euskararen historia behetik
}

\author{
Manuel PADILLA MOYANO \\ UPV/EHU, IKER UMR5478
}

\section{Sarrera ${ }^{1}$}

Liburu hau justifikatzen duen dokumentazioa lapurteraz idatzitako berrogeita hamar gutunetako bilduma da, 1757ko otsail eta apirilaren artean datatua. Le Dauphin izeneko ontzi kortsarioak Louisbourgera karreiatu behar zituen gutunak (Île Royale, egungo Cap Breton uhartea, Quebec). Baina Zazpi Urteko Gerlarekin (1756-1763) Frantziko Erresumak Kanadako kostalde atlantikoan zituen kolonietako egoera arras nahasi zen. Ehunka frantses ontzirekin agitu bezala, ingelesek Le Dauphin harrapatu zuten eta Londresera eraman. Duela urte batzuk Xabier Lamikiz historiagileak ontzi haren dokumentazioa atzeman du National Archives erakundean (Londres), hain zuzen High Court of Admiralty delakoan. Itsasontziaren epaiketaren paperak, kortsu agiria, kontuak, kontratuak eta bestelakoak TNA, HCA 32/180 (1) kutxan daude. Aldiz, korrespondentzia osoa TNA, HCA 30/264 kutxan dago.

Gutuneria honetan Lapurdiko hamar barietate lekukotuak dira, euskalkiaren eremuaren gehiena ordezkatuz. 37 eskuk 50 letra idatzi zuten, 48 igorleren mezuen bideratzeko; orotara 10.300 hitzez osatutako mikro-corpusa dugu Le Dauphin gutuneria. Izari handi batean, euskararen literatur tradizioa lapurteraren testu inprimatuen gainean eraikia da. Dena den, dialekto horren historiaz oraintsu arte genekiena gehienbat erlijiozko testuetan oinarritua zen. Testuinguru horretan, Le Dauphin-en dokumentazioaren aurkikuntza beste motatako testuen eskasiaren arintzera dator eta, gehiago dena, bide berriak zabaltzen dizkio euskalaritzari. Lehenik, argia ematen dielako populu xumearen epistola usantzei eta, oro har, XVIII. mendeko lapurtarrek zuten euskaraz idazteko ohiturari. Bigarrenik, lapurteraren 1757ko hizkuntza

1. Eskerrak bihurtzen dizkiot Xabier Lamikizi, bere aurkikuntza hizkuntzalarien esku uzteagatik, eta Xarles Videgaini, nitan hastapenetik izan duen fidantzagatik eta erakatsi dizkidanak ororengatik. Nire esker ona, halaber, Beñat Oyharçabal eta Blanca Urgelli, lan honi egin dizkioten ohar ezin pagatuzkoentzat, bai eta haien gidaritza eta sostenguarentzat. 
egoeraren argazkia delako eta, menturaz, iraganeko hizkuntz aldakortasuna aztertzeko hobekien baliatuko zaigun lekukotasuna. Hirugarrenik, euskararen historiari heltzeko hurbiltze berri bat ahalbidetzen duelako, hain zuzen ere hizkuntzaren historia behetik ("from below") izendatu dena.

Lan honetan Le Dauphin-eko euskarazko gutuneriaren hainbat alderdi interesgarri aztertuko dugu. Hasteko, idazki pribatuen gaineko ikerketaren premia aipatuko dugu, batez ere maila apaleko jendearen ego-dokumentuei doakienean (§ 2). Ondoren Le Dauphin itsasontziko dokumentazioaren garrantzia azalduko dugu, euskararen corpus historikoan kokatuz eta gainerateko eskutitzekiko desberdintasunak kontsideratuz (§3). Laugarren atalean Le Dauphin-eko letren igorleez arituko gara, egiletasun aferei erreferentzia eginez (§ 4.3), bereziki idazlarien existentziari, euskararen historian lehenbiziz lekukotzen duguna. Gutun egileak XVIII. mendeko Lapurdiko egoera soziolinguistikoan kokatuko ditugu, generoaren eta alfabetzearen gaineko gogoeta eginez (§ 4.5); atala epistola edukiaren eta gaien bista orokor batekin hetsiko da. Lanaren azken partean idaztearen esperientziaz arituko gara. Europako jende ez osoki alfabetatuaren idazmen eta gutun herrikoien eskemara hurbildurik (§ 5.1), Le Dauphin bildumako bi emazteren idatz moldeak konparatuko dira (§ 5.2). Gero gutungintza herrikoiaren ezaugarri nagusi diren epistola formulak aztertuko ditugu: Le Dauphin-eko egitura errepikatuenen funtzioak eta maiztasuna baina, oroz gainetik, Europako hainbat hizkuntzatako eskutitzetan atzeman diren bat etortze harrigarriak, tradizio paneuropar baten lekuko (§ 5.3). Finitzeko, epistola usantza haien transmisioaz gogoetatuko dugu (§ 5.4).

Gure helburu nagusia hau da: ego-dokumentuen ikerketan eta epistolografian nazioartean baliatzen ari den hurbiltzea euskal ikasketetara ekartzea, Le Dauphin gutuneriak hauei zabal diezazkiekeen bideak seinalatuz. Xede azkena litzateke euskararen historia behetik egiteko lehen urrats baten oinarriak finkatzea. Gutunetako datu linguistikoak behar denean aipatuko baditugu ere, gure hipotesien adigarri, lan honetan ez da 1757ko lapurteraren isla den bilduma honetako hizkuntzaren deskripzio sistematikorik eginen.

\section{Ego-dokumentuen garrantzia hizkuntzaren historian}

Aro Modernoa denaz bezainbatean, Mendebaldeko hizkuntzen historia gehienak hizkuntza inprimatuen istorioak dira (Elspaß 2012: 156). Hortaz, hizkuntzaren historiaren ikuspegi zabal eta osoaren erdiesteko, funtsezkoa izanen da ahalbait aldi, eremu, barietate, gai eta testu mota ordezkatuko dituzten ahalbait lekukotasun gehienen kontuan hartzea. Egia da euskararen corpusaren izaerak —neholaz ere munduko hizkuntzen artean urrienetakoa izan gabe - jada behartu dituela ikertzaileak hatsarre horren pean lan egitera, material suerteak oro bilduz eta baliatuz. Aldiz, besterik ez dugulako sentipenean lotzen zaio, hein batean, euskara historikoaren hainbat testigantzen aztertzeari. Nire ustez, egoera partikular horrek badu abantailarik, euskararen historia eta filologian beti izan baita genuena gogoan ukaiteko beharra, inguruko erdaren kasuetan kontuak oso bestelakoak izan direnean.

Lekukotasun edo iturri mota diferenteei doakienean, dokumentu pribatuek sekulan baino arreta handiago jasotzen dute hurbiltze diakronikoaz lan egiten duten ikertzaileengandik. Besteak beste, dialektologia, soziolinguistika, pragmatika, diskurtsoaren analisia, alfabetatzea, literatura edo kulturaren historia bezalako adarretan — hizkuntzari lotuak baizik ez aipatzearren - aitzinamenduak egin dira, eta egiten, dokumentu pribatuen ikertzeari esker. Garai zaharretara gibelatuz, lekukotasun idatzietan oinarritu beharrak ez dakar mintzatuaren 
historia ezin egin daitekeenik. Hizkuntza mintzatua vs. hizkuntza idatzia oposizio tradizionalak ñabardurak onartzen ditu. Koch \& Oesterreicher-ek (1985) kontzeptualizazio bat eskaintzen dute, beren 'hurbilaren hizkuntza' (Sprache der Nähe) vs. 'distantziaren hizkuntza' (Sprache der Distanz) ideiarekin. Labur bilduz, bi ardatz proposatzen dute: bitartea (ahotsa/hitz idatzia) eta testuaren sortzapen linguistikoa. Sortzapen hori hurbiltasuna (ahozkoa, informala, ezplanifikatua) eta distantzia (jasoa, formala, planifikatua) bitasunaren arteko continuum batean plaza daiteke. Continuum horren bi muturretan, etsenplutako, solasaldi intimo bat eta lege kontratu bat koka genitzake, eta horien artean hurbiltasuna/distantzia determinatzen dituzten hiru parametroen arteko konbinazio guztiak. Halaber, denbora, espazioa, gauzatze pribatu edo publikoa bezalako faktoreek ere moldatzen dute testuaren sortzapen linguistikoa.

\begin{tabular}{|l|r|}
\hline \multicolumn{2}{|c|}{ 1. TAula. Hurbilaren hizkuntza vs. distantziaren hizkuntza } \\
\hline Hurbiltasuna & Distantzia \\
\hline ahozkoa & kultoa \\
informala & formala \\
ez-planifikatua & planifikatua \\
pribatua & publikoa \\
ber espazioan & espazio diferentetan \\
zuzenean & geroratua \\
familiarra & ez familiarra \\
\hline
\end{tabular}

Dokumentu pribatuen artean, hizkuntzalaritza historikoari ego-dokumentuak interesa lekizkioke gehien: autobiografiak, egunkariak eta gutunak; Martineauk (2007: 202) kontabilitate liburuak ere proposatzen ditu. Helburu pribatuz ekoitzi testuak, eta oroz gainetik gizarte maila apaleko egileenak, aiseago urruntzen dira preskripziotik edo estilo eta errejistro landuek ekartzen ohi duten distantziatik. Ahantzi gabe hein batean distantzia ere osagai dutela — hala zenbait adierazpide kodeturen erabilpenaren nola denbora eta espazioarekiko aldearengatik-, gutunak beste zein-nahi idazki mota baino hurbilago dirateke hizkuntza mintzatutik. Horrela, Ipar Irlandako emigranteen eskutitzek "offer us considerable expectation for finding evidence of spech" (Montgomery 1995: 33). Le Dauphin-eko gutunek, gure ustez, Schneider-ek (2002: 71) dokumentu idatziei aldakortasun-analisiaren objektu izateko ezarri dizkien eskakizunak betetzen dituzte: ${ }^{2} 1$ ) testu idatziek hizkeratik (batez ere errejistro

2. Hizkuntzalariek beste dokumentu bildumetara jo dute. Nabarmena da Bourciez-en bildumako euskal testuen kasua (Aurrekoetxea \& Videgain 2004), Iparraldeko udalerri guztiak ordezkatzen dituelako. Baina ezin ahantz Seme Prodigoaren parabolaren itzulpena herri bakoitzeko errejentari eginarazi zitzaiola; beraz, testu horiek urrun dira egoera komunikatibo batetik zein egile tipologiaren aniztasunetik. 
informaletarik) ahal bezain hurbil izan behar lukete; 2) adin talde, genero eta gizarte maila diferentetako hainbat egilek idatziak izan behar lukete, ahal dela aldakortasun estilistikoa ere erakutsirik; 3) aztertu nahi den fenomenoan aldakortasuna erakutsi behar dute; eta 4) testuek luze izan behar lukete, bederen zenbait fenomenoren analisi kuantitatiboen egiteko bezain. Guztiagatik, ego-dokumentuak iturri ezin utzizkoak dira hizkuntzaren historialarientzat:

They are special, firstly, because they are as close to speech as non-fictional historical texts can possibly be and therefore cast light on the history of natural language. Secondly, they can fill 'blank spaces' left by traditional historical linguistics' teleological perspective of language histories and its focus on literary texts and formal texts from higher registers. Moreover, they can constitute the basis of a 'language history from below' in its own right (Elspaß 2012a: 156).

Izan ere, hizkuntzen historia tradizionalek barietate estandarrei —edo haien eratzean oinarri hartu direnei- lehentasuna eman ohi badiete, lan berrienak hizkuntza aldaketaren berri argiago ematen ahalegindu dira, gutxiago ezagutzen ziren barietateak deskribatzeari ekinez (Dossena \& del Lungo Camiciotti 2012: 6). Irizpide sozio-demografikoetara bihurtuz, hizkuntza historiografia tradizionala mugatu izan da ez jadanik testu inprimatuetara, baina gizartearen goi mailako kideek egin dituztenetara ere. Maila praktikoan zilegi izan daiteke: batetik, denbora luzez soilik eliteko kideek zezaketen argitara eman; bestetik, behe mailakoek anitzez gutiago ekoitzi dute, idazten hasi zirenetik, goi mailakoek baino (Elspaß 2012a: 159).

Anitzetan ego-dokumentuak hizkuntzaren historiaren hutsuneen argitzeko giltzarriak gertatzen dira. Euskararena baino corpus historiko zabalago eta aberatsagoa duen nederlanderaren kasuan, National Archives of Kew direlakoetan aurkitu gutun konfiskatuek — tartean Le Dauphin bildumaren garaikideek - gakoa eman dute hizkuntza horren historiaren zenbait lausoguneri argia emateko. ${ }^{3}$ Letters as Loot proiektuaren arduradunen hitzetan, "The letters are a gold mine for researchers wanting to study the everyday language used by men and women during this period" (van der Wal d.g.). Nahiz berrogeita hamar testu izan, ber hitzak balia ditzakegu Le Dauphin ontziko euskarazko dokumentazioarendako. Hurrengo atalean ikusiko denez, gutunek XVIII. mendeko lapurteraren ezusteko ezaugarrien berri ematen digute: arkaismoak zein berrikuntzak izan, edo egundaino beste eremukotzat genituen formak eta fenomenoak, euskalkiaren egiazko argazki batek erakuts lezakeen aldakortasunaz hornituak.

Ikuspegi soziolinguistiko batetik, gutuneria honek argia eman diezaioke garaiko Iparraldeko euskal herrietako alfabetatzeari: irakur eta idazmenaren erakaspena, euskararen

3. Le Dauphin ontziko gutunak bezalaxe, Londreseko National Archives of Kew erakundean XVIII. mendeko hainbat hizkuntzatako dokumentazioa aurkitu dute. Haren tamainagatik, deigarriena nederlanderaren kasua da, 38.000 eskutitzekin. Horien ikertzeko abiatu da Letters as Loot proiektua (Leideneko Unibertsitatea), Marijke van der Wal-ek zuzendua. Hizkuntzaz denaz bezainbatean, gutunek informazio aberatsa eskaini dute zenbait fenomenoren bilakaera argitzeko, iraganaldiko aldakortasun ezezagun baten berri emanez (van der Wal, Rutten \& Simons 2012). 
gramatika kodetze maila eta fenomeno hauek Lapurdiko gizartean zuten banaketa bezalako gaiak aztertzeko bide ematen digu. Alderdi literariotik, Le Dauphin-en dokumentazioa intimitatearen eta egunerokotasunaren adierazpeneko ezagupide ezin egokiago da. Besteak beste, diskurtsoaren antolakuntza, pragmatika edo estilistikaren gaineko informazioa eskaintzen digu. Finitzeko, interes historikoa ere ukaezina da.

\section{Le Dauphin-eko gutuneria euskararen corpus historikoan}

1757koa den Le Dauphin-eko euskarazko gutunerian badugu 48 igorle, 50 gutun eta 37 esku (xehetasunendako ikus § 4). Corpusaren tamaina 10.275 hitzekoa da, ${ }^{4}$ eta frantsesezko pasarteak kenduz —nagusiki helbideetakoak— 9.491n gelditzen da. Erran behar da itsasontziak euskarazko baino frantsesezko letra gehiago karreiatzen zuela: 50 eta 107, hurrenez hurren. ${ }^{5}$ Erdarazko gutuneriaren azterketa lan honen helmenetik kanpo gertatzen da: ez ditugu horien argazkiak, ez eta gutun bakoitzaren gaineko gutieneko jakingarriak (igorlea, hartzailea, herria eta data). Etorkizuneko ikerlanetan bi gutun multzoak erkatu beharko lirateke, gutienik, parametro diatopiko (nondik igorri ziren batzuk eta besteak) eta diastratikoen arabera (Lapurdiko herri elebidunetan zein gizarte taldekoek baliatzen zuten frantsesa, eta nori idazteko).

Guztiarekin ere, ditugun datuekin posible da zenbait ildoren markatzea. Le Dauphin-eko Lapurdiko gutun guztien artean euskara minoritarioa izan arren — bat biko proportzioan-, Frantziako beste herrialdeetan gerta zitekeenari konparatuz gero abantaila handitan da. Kasu batentzat, soldado bearnesen gutun corpuseko idazki guztiak (Staes 1979-1992) frantsesez idatziak dira, zehazkiago français régional deitu denaz (Moreux 1991). Konparazioa ez da guztiz orekatua, hamarkada zenbait berantagokoak direlako soldaduska gutunak; halere, guztiak frantsesezkoak izateak zerbait seinalatzen du, eta areago gogoratzen bada bearnesak idatzizko tradizio luze eta sendoa zuela.

4. Egiazki, hizkuntza handietan halako kopuruek eskasegi iduri lukete. Nazioartean gehien aipatzen diren proiektuetako batek, Corpora of Early English Correspondence delakoak (CEEC), 5.961 eskutitz biltzen du [<http://www.helsinki.fi/varieng/domains/CEEC.html>]. Kontrastea are biziago da lehen aipatu diren nederlanderazko 38.000 gutunei alderatuz (van der Wal, Rutten \& Simons 2012). Aldiz, suomi emigranteen gutuneria aztertzeko baliatu den corpusa 45 eskutitzekoa da (Laitinen \& Nordlund 2012). Orobat, 45 testutakoa da Bearnoko soldadoen gutunen corpusa (Staes 1979-1992).

5. Ohart bedi Lapurditik igorriak baizik ez direla zenbatu; haietarik landa zenbait gutun Bordeletik idatzi zen, adibidez. 


\begin{tabular}{|c|c|c|}
\hline \multicolumn{3}{|c|}{$\begin{array}{l}\text { 2. TAula. Le Dauphin-eko gutunen jatorria: } \\
\text { euskara vs. frantsesa (lagina) })^{6}\end{array}$} \\
\hline \multirow[t]{2}{*}{ Jatorria } & \multicolumn{2}{|c|}{ Gutun kopurua } \\
\hline & Euskaraz & Frantsesez \\
\hline Ahetze & 2 & - \\
\hline Azkaine & 3 & - \\
\hline Baiona & 1 & 18 \\
\hline Bidarte & 2 & 1 \\
\hline Donibane Lohizune & 6 & 13 \\
\hline Getaria & 8 & - \\
\hline Hazparne & - & 2 \\
\hline Hendaia & 4 & 1 \\
\hline Sara & 9 & 7 \\
\hline Senpere & 5 & 2 \\
\hline Urruña & 2 & - \\
\hline Ziburu & 5 & 8 \\
\hline Jatorri ezezagun & 3 & - \\
\hline Orotara & 50 & 52 \\
\hline
\end{tabular}

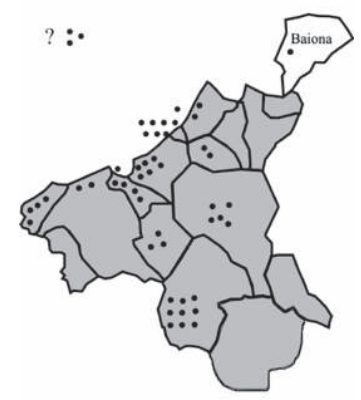

1. IRUDIA. Le Dauphin-eko gutuneriaren banaketa lapurteraren eremuan. Galdera ikurra jatorri ezezaguneko gutunei doakie.

6. Euskarazko gutun guztiak kontuan izan baditugu, frantsesezkoekin ez da posible izan. Haien gainean dugun zatikako informazioa dela kausa, lagin bat baliatu zaigu, kasik corpusaren erdira iristen dena. Zehazkiago, igorlea eta herria ezagutzen dizkiegun gutunen multzoak du lagin hori osatzen. 
Euskararen corpus historikoan 1415etik 1800era doan tartean baditugu izaera diferentetako eskutitzak, hainbat euskalkitan. Exhaustiboa izan gabe, hona hemen zerrenda bat:

\begin{tabular}{|c|c|c|c|}
\hline \multicolumn{4}{|c|}{ 3. TAULA. Euskarazko gutunak (1415-1800) } \\
\hline Urtea & Testua & Euskalkia & Hitzak \\
\hline 1415 & Nafarroako zerga biltzaileena & goi-nafarrera & 53 \\
\hline 1537 & Joan Zumarragakoarena & mendebaldekoa & 356 \\
\hline 1584 & Bertrand de Etxauzena & behe-nafarrera & 163 \\
\hline 1596 & Isabel Lobiano (Satr. 1987: 33) & gipuzkera & 60 \\
\hline 1598 & Simancaseko espioitza gutunak & goi-nafarrera & 617 \\
\hline $1616-1617$ & Erronkari eta Zuberoaren arteko gutuneria & zub. erronk. & $?$ \\
\hline 1622 & Azpeitikoak & gipuzkera & 353 \\
\hline 1626 & M. Seinich-enak & lapurtera & 90 \\
\hline 1655 & Domingo Lardizabalena & gipuzkera & 89 \\
\hline 1664 & Jean Peruskirenak & behe-nafarrera & 502 \\
\hline 1680 & Urruna eta Hondarribia arteko gutuneria & lap. nafarrera & 1.133 \\
\hline 1683 & Fermin de Basabiluasorena & kostatarra ${ }^{8}$ & 88 \\
\hline 1693,1699 & J. Elizalderenak & goi-nafarrera & 501 \\
\hline XVIII. m. & Izeba-ilobenak (Contr. 141-142) & goi-nafarrera & 236 \\
\hline
\end{tabular}

7. Urtubiako damaren euskara —hogei gutunetarik hemeretziren egilea (Orpustan 2010: 137)—ez da aise sailkatzen. Urruñan plazatua, haren familiak etorki giputz-nafarra bide zuen. Ondorioz, "la configuration linguistique et dialectale de la correspondance basque de la dame d'Urtubie apparaît au lecteur actuel incontestablement mêlée. [...] C'est qu'en phonétique [...], en morphologie, en lexique, de nombreux traits relèvent du domaine des dialectes hispaniques" (ibid. 161).

8. Sarasolarentzat Basabiluaso Bizkaitik idatzi zuen bizkaitar bat zatekeen (1983: 131), eta haren eskutitza, Donibane Lohizunera igorria, XVII. mendean kostaldeko hirien arteko harreman orain baino estuagoen lekuko litzateke. Hortaz, Basabiluasok nahi argi bat erakutsi bide zuen bere mintzoaren lapurteratzeko. Sarasolarentzat "estas diferencias se articulan sobre una base vizcaína cuya manifestación más palpable sea quizá la [neutralización de las sibilantes] [...], diferencia que ya se había neutralizado en parte del territorio de habla vizcaína (y por supuesto Bilbao) para cuando esta carta fue escrita" (ibid.). Baina guretzat ez da, gutunean zehar, bizkaieraren aztarnarik, ez bada lasterreena bokalismoa, Urgellek gaztigatu digunez. Txistukarien neutraltzeaz gehiena oraino erraiteke dago, eta gutunean datzana gehiago litzateke lapurtera bizkaitar baten ahoan. 


\begin{tabular}{|c|c|c|c|}
\hline 1757 & Le Dauphin & lapurtera & 9.491 \\
\hline 1747,1763 & Larramendirenak & gipuzkera & 1.563 \\
\hline 1761 & Jose eta Josefarenak (Satr. 1983) & gipuzkera & 1.240 \\
\hline $1769-1799$ & Sara eta Baztan arteko gutuneria & lapurtera & 706 \\
\hline 1788 & Donibane Lohizuneko udalarenak & lapurtera & 663 \\
\hline
\end{tabular}

Bistan da, Le Dauphin-ekoa ez da euskaraz dugun gutuneria bakarra, baina haren izaera eta tamainari erremarkatuz gero ez da, euskararen corpus osoan, deus hari konpara lekiokeenik. Goiko zerrendari soño bat egitea aski da ohartzeko gutun egile gehienak handikiak izan direla: Elizaren kargudunak eta zerbitzari publikoak, nagusiki. Maila apalagoko egileenak, aldiz, ez dira iristen Le Dauphin bildumaren tamainara: Azpeitiko hiru gutunak 75 lerrotan baizik ez dira hedatzen, M. Seinich-enak eskutitz baino gehiago dira ohartxoak, eta J. Peruskirenak edo Elizalderenak bostehun eleen mugan gelditzen dira. Egiletzari doakionean, multzo guztiak egile bakar edo bikoak dira. 3. TAULAko dokumentuen artean, beraz, nehon ez da 50 eskutitzeko bildumarik, ez eta gutiagokorik ere: xede ofizial zein pribatuko izan, goi ala behe mailako kide batek ekoitziak, euskarazko gainerateko korrespondentziak eta eskutitz solteak urrun daude Le Dauphin-en dokumentaziotik tamainaz, baina batez ere egileen aniztasunaz.

Zifra horietarik haratago, Le Dauphin itsasontziko gutuneriak abantaila handi bat du: XVIII. mende erdiko lapurteraren hizkuntza egoera islatzearena. Gutunek, konkretuki, Lapurdiko hamar barietate ordezkatzen dute, eta guztiak 1757ko otsailaren 2tik apirilaren lera doan tartean izan ziren idatziak. Xede komunikatibo duten idazki pribatuak izateagatik, eta are gehiago jende apalak eginak, ezagutzen dugun beste zein-nahi testuk baino modu fidagarriagoan islatzen dute XVIII. mende erdiko lapurtera mintzatua, 1. atalean azaldu den hurbilaren hizkuntza hura ematen duten idazkiak baitira.

Izan bedi honen guztiaren adigarri fenomeno fonologiko bat: bokal altuen ondoko epentesi anti-hiatikoak. Le Dauphin-eko lapurterazko gutunetan $i$ ondoan [j] irristaria ager daiteke (berrijak 20, guzijek 34, bijotz 34, amudijuaren 34), eta $u$ ondoan [ $\beta$ ] ezpainkaria (estatuba 38, zindubela 11); batzuetan biak hitz berean ere (perfesiyonatuba 29). Lapurteraren tradizio inprimatuan epentesi hauen maiztasuna ez denean sekulan \% 1era ere iristen, 1757ko gutunetan agertze testuinguru posible guztien \%45ean eta \%24an lekukotzen dira, hurrenez hurren (Padilla 2015). Beste maila batean, 20. gutuna osoki egina da noka molde alokutiboan, lapurteraren corpus historikoan lekukotu gabeko formak ageriz (nijalabin 'nabilen', zijaetanen 'zitzaidanan'). Labur erraiteko, nekez igurika genezakeen aldea gerta daiteke ego-dokumentuen eta euskalkiaren idatzizko tradizioaren artean. Beraz, Le Dauphin ontziko gutunak lehen mailako datu iturri bihurtzen dira lapurteraren historiaren egiteko tenorean, hizkuntzaren historiari behetik (from below) lotzeko aukera emanik ere.

\section{Le Dauphin gutuneria: egileak eta gaiak}

Atal honetan Le Dauphin bildumako gutunak jatorri anitzetakoak direla ikusirik (§ 4.1), hartzaileak eta igorleak ere soziologikoki askotarikoak direla ikusiko dugu, eta horregatik ere 
ondorioak askotarikoak izanen dira. Egiletasunaren aferaren aztertzean, ezustean atzeman dugu gutun batzuk idazlariak eginak direla (§ 4.2). Emazteen proportzio altuaz eta alfabetatzeari lotutako gaiez aritu ondoan ( $(4.3$ ), gutuneen gai nagusiak ilustratzen dituzten pasarte batzuk ekarriko ditugu (\$ 4.4).

\subsection{Igorle eta hartzaileez}

\begin{tabular}{|c|c|c|c|c|}
\hline \multicolumn{5}{|c|}{ 4. taUla. Le Dauphin gutuneriaren egileak eta hartzaileak } \\
\hline $\mathrm{zk}$. & Jatorria & Igorlea & Ahaidegoa & Hartzailea \\
\hline 1 & Urruña & Martin de Arrunde & aita & Martin de Arrunde \\
\hline 2 & Hendaia & * Marie d'Etcheverry & ama & Pierre Daguerre \\
\hline 3 & Hendaia & Gachina de Biscarrondo & arreba & Patchiqu de Biscarrondo \\
\hline 4 & Hendaia & Gachina de Biscarrondo & arreba & Martin Josepe de Biscarrondo \\
\hline 5 & Sara & Catalin Lalanne & esposa & Esteben Gourdo \\
\hline 6 & $?$ & * Maria de Molleres & adiskide & Bitor \& Bernat de Farandiret \\
\hline 7 & Sara & * Miguel Harismendy & aita & Bernard Harismendy \\
\hline 8 & Azkaine & Maria de Bortairay & kusina & Joannis Hiribarren \\
\hline 9 & Hendaia & Gaçina Diyarz & esposa & Joannes Hiraburu \\
\hline 10 & Sara & Martin Borda & aita & Andreco Borda \\
\hline 11 & Senpere & * Maria Dihitx & ama & Haurra Maria Hiriart \\
\hline 12 & idem & *idem & idem & idem \\
\hline 13 & Getaria & Joanna de Salla & hauzo & Jean Castillou \\
\hline 14 & Sara & Martin Durruitz & aita & Domingo Durruitz \\
\hline 15 & Getaria & * Joanna de Castillou & alaba & Jean Castillou \\
\hline 16 & Senpere & * Joanes de Matet & aita & Joannes de Matet \\
\hline 17 & $?$ & $?$ & hauzo? & Bernat Haroqui \\
\hline 18 & Getaria & * Maria de Lamarq & ama & Bernat de Lupoy \\
\hline 19 & Sara & Joannes d'Etcheverry & aita & Joannes d'Etcheverry \\
\hline 20 & Donibane & Marie Darburu & ama & Marie (Duhalde) Harboure \\
\hline 21 & Ziburu & * Jean Lafitte Bourguignon & aita & Joanis Lafitte Bourguignon \\
\hline 22 & Sara & Joanna de Bidart & ama & Joannes d'Etcheto \\
\hline 23 & Sara & * Piarres d'Etcheverry & aita & Joannes d'Etcheverry \\
\hline
\end{tabular}




\begin{tabular}{|c|c|c|c|c|}
\hline 24 & Senpere & * Betri d'Etcheberry & aita & Joannes Etcheberry \\
\hline 25 & Sara & * Martin d'Etchart & osaba & Joannes d'Etcheverry \\
\hline 26 & Baiona & Cathalin Marie Berrogain & adiskide & Catherine Laborde \\
\hline 27 & Azkaine & Marittipo de Subiet & esposa & Laurens Perusqui \\
\hline 28 & Ziburu & Cathalina Ithurriague & arreba & Gabriel Ithurriague \\
\hline 29 & Ziburu & Pierre d'Etchevers & anaia & Pierre d'Etchevers, \\
\hline 30 & Senpere & Martin Larralde & osaba & Saint Martin de Duronia Mirande \\
\hline 31 & Bidart & * Katalin Duat & esposa & Pierre Latiga \\
\hline 32 & Ziburu & * Maria de Saint Martin & ama & Joanis Diharce \\
\hline 33 & Getaria & Betry Daguerre & anaia & Martincho Daguerre \\
\hline 34 & Donibane & Terecha Labadia & ama & Joanis Dupui \\
\hline 35 & Getaria & * Catharine Desclaus & ama & Martin de Heuty \\
\hline $36 a$ & Azkaine & Gachina Saint Pée & koinata & Catherine Gelos \\
\hline $36 b$ & Azkaine & Pierre Etchegaray & koinatu & Catherine Gelos \\
\hline 37 & Donibane & Gana Haurra de Fumat & ama & Adrien Salla \\
\hline 38 & Getaria & * Joana Duhalde & esposa & Janne Castillou \\
\hline 39 & Urruña & Haraneder apeza & osaba & Pierre Echegoyen \\
\hline 40 & Ahetze & David Borrotra & aita & Martin Borrotra \\
\hline 41 & Donibane & Machume Basterreche & ama & Esteben Lafontaine \\
\hline 42 & Getaria & * Sabadina de Clauset & ama & Martin de Darango \\
\hline 43 & Getaria & * Joana Aprendisdeguy & esposa & Martin de Darango \\
\hline 44 & Bidart & $?$ & arreba & Gracian Goute \\
\hline 45 & Donibane & Estonta Durquiet & arreba & Martin Durquiet \\
\hline 46 & Donibane & Maria de Bordachipi & ama & Pierre Lahitun \\
\hline 47 & Sara & Marie d'Iturriague & ama & Estebe de Echegaray \\
\hline 48 & Ahetze & Joannes Larralde & aita & Betry Larralde \\
\hline 49 & $?$ & Francha Barrere & esposa & Pierre Hayete \\
\hline
\end{tabular}

Eskutitzen erdien kasuan, gutun-azalean hartzaileren estatusari lotutako informazioa agertzen da. Jakina, itsas jendeari dagozkion ogibideak gailentzen dira: Esteben Gourdo, 
marinier (5), Joannes Hiraburu, charpantie marein (9), Andreco Borda, marinier $m$. de grave (10), Jean Castillou, $m^{e}$ de grabe (13, 15 \& 38), Joannes d'Etcheverry, marinier (19), Joanis Lafitte, marinier (21), Joannes Etcheberri, chanpartier et menusier (24), Gabriel Ithurriague, marinier (28), Pierre d'Etchevers, $M^{\text {tre }}$ charpantie de navire (29), Saint Martin de Duronia Mirande, Maitre capitain de navires (30), Martincho Daguerre, marinier faisant la peche de la morue (33), Joanis Dupui, mattalot (34), Adrien Salla, marinier (37), Pierre Lahitun, de la navire Le Roi (46) edo Pierre Hayete, maitre cordonnié (49). Batzuek etorkiari egiten diote erreferentzia: Joannes d'Etcheto, Sara Olhaco errotako semea (22), Martin de Heuty, sieur de Mariltchenea (35), Martin de Darango, sieur de Piarrenea (42, 43). Sehi eta neskamerik ere ageri da: La presente soit rendüe à Monsieur de Lalongue, bourgois, pour remettre à Martin Borrotra, son garson, s'il lui plait (40), eta agian Marie Harburu, demeurent ches Monsieur de Laborde, Trezorier du Roy (20).

\subsection{Igorle, idazle eta idazlariez}

Idazki mota bezala, gutunek berezitasunak dituzte egiletzari eta, oro har, haien sorkuntzan parte hartzen duten agenteei doakienean. Le Dauphin gutuneriaz denaz bezainbatean, hiru pertsonaia bereiziko dugu: igorlea (kodetzen den mezuaren egilea), idazlea (igorlearen izenean gutuna idazten duen laguna, izan dadin familiako, hauzo ala adiskidea) eta idazlaria (gutuna ofizioz idazten duena). ${ }^{9}$ Nabarduretan sartzeko beharrik ikusiko ez denean, hots, igorlea eta idazlea bat datozenean, egile terminoa lehenetsiko dugu. Bildumako gutun gehienek eskemarik sinpleen honi obeditzen diote: pertsona batek luma har, eta bere mezua papereratzen du, bere buruari diktatuz. Eskema horretatik atera gabe, gutun anitzetan igorleak ondoan duen norbaiten mezuak jasotzen ahal ditu, normalean zeharkako estiloan: ${ }^{10}$

Apa Xapanak goranzi, haren galzardi gorrijak non tuzu? Gana Xume asarre da zure kontra, merisi du zureganik; gusama ere bai. Marie d'Etcheverry $(2,2 r)$.

Pentsatzekoa da gutunen idazteko eta irakurtzeko ekintza, etxe batzuetan, kolektiboa izan zitekeela. Eskutitz batzuetako pasarteek horrela sujeritzen baldin badute, ondokoan kasik entzun dezakegu polifonia:

Arrebak goraintzi, osaba eta izeba guziek goraintzi, kusina guziek goraintzi, Etxegaraiko familia

9. Ez da gure asmoa gutungintzaren parte hartzaileen rolen definizioaren gaineko eztabaida teorikoan parte hartzea. Azken urteetan proposamen batzuk kontrajarri dira; Dossenak horien konparazio egokia egin du (2012: 20).

10. Atal honetan gutunetako aipuak grafia eguneratuan ematen dira, hots, edizioaren B bertsiotik jasoak. Hautua arrazoin praktikoetan justifikatzen da: pasarteak hizkuntzaz landako helburua duten ataletan emanak izanik, irakur aisetasuna lehenetsi dugu. Interes paleografikoa duenak jo beza edizioaren A bertsiora. Aldiz, 5.2 eta 5.3 ataletan kontrako irizpidearen arabera eginen da, bertan grafiak inport duelako. 
guziak goraintzi, Errotako familia guziak goraintzi, Agerreko familia guziak goraintzi, Kamietako familia guziak goraintzi; andregaia ezkondu da Hausteiko Kadetekin, seme handi batekin daude.

[...] Apa Landaburukoak, Mariak, Maxume Estebenekok, Gaxina xume Kastienekok, Gaaxik... Guzi-guziek gorainzi. Bitor eta Beinat, ene adiskide eta hauzo maite-maitiak, goraintzi darotzuet partikularzki nik, letraren egiliak, guzien gainetik, Maria de Molleres. Etxegaraiko Haurra Mariak egina. Otsailaren 20an egina, 1757. Lapitzeko andregaiak goraintzi mila-mila.

Orai konpreni zazue guk zuek zein maite zaituztegun: kandela bat ere erre ginduen hunen egitian, bertziak libertizionian eta gu hunen egiten $(6,3 \mathrm{r}-\mathrm{v})$.

Hiru kasutan preseski aipatzen da gutunaren egileak beste norbaitengana jo duela bere mezuaren izkribatzeko. Honela diote:

[...] Marie d'Etcheverry. [Marjinean idatzia] Hauzukuak gorantzi. Don Qochek egiñ du letra hau (2, $2 \mathrm{r})$.

[...] goraintzi darotzuet partikularzki nik, letraren egiliak, guzien gainetik, Maria de Molleres. Etchegaraiko Haurra Mariak egina (6, 3r).

Gelditzen naiz zure espos fidel maite, Katalin Duat. Nik, Oierek, eta aitak eta kusinak milla goraintzi $(31,2 v)$.

Horrelako kasuetan igorlea eta idazlea bereizi beharretan gara. Kontua da ageriko aipamen hauek erakusten duten baino hedatuagoa zatekeela idazlarien zerbitzuen baliatzea. Soilik dokumentazioa herrika multzoka eta erkatu ondoan ikusi da gutun batzuk ber eskuak eginak direla: ber dispositio eta kaligrafiak, gehi grafia sistema berak hala salatzen ahal dute. Atzeman ditugun esku kidetasunak 5. TAULAn biltzen dira. Preseski gaztigatu nahi dugu behin-behineko emaitzak agerrarazten direla hemen: batetik, esku kidetasunen edireitetik idazlarien parte hartzea igar badaiteke, ez edireiteak ez dezakeelako idazlarien absentzia erakuts (negativa non sunt probanda); bestetik, hizkuntzan oinarritutako konparazio sakon batek informazio gehiago ekar lezakeelako. Mementoko bi gutun mota bereizi behar da: 1) esku bereko multzoetan sartzekoak (bost eskuk 18 gutun izkribatu baitute, ustez idazlarien lana salatzen duena), eta 2) esku bakarrak egindakoak. Ikusi dugu esku bakarreko 32 gutunetarik hiru hurbileko idazle batek eginak direla, baina ez dakigu beste 29 en arteko zenbat ez diren holografoak, eta balizko heterografoen gibelean noraino ikusi beharko litzatekeen idazlari baten parte hartzea. 


\begin{tabular}{|l|l|l|l|}
\hline \multicolumn{5}{|c|}{ 5. TAULA. Gutunetako eskuak herrika } \\
\hline & $\begin{array}{l}\text { Esku bereko gutun } \\
\text { multzoak }\end{array}$ & $\begin{array}{l}\text { Esku-kidetasunik } \\
\text { gabeko gutunak }\end{array}$ & $\begin{array}{l}\text { Idazlearen } \\
\text { aitorpena }\end{array}$ \\
\hline Ahetze & & 40,48 & \\
\hline Azkaine & & $8,27,36 a, 36 b$ & \\
\hline Baiona & & 26 & 31 (Oyer \\
\hline Bidarte & Diratçabal)
\end{tabular}

Kidetasun hauen erakusgarri hoberena da Senpere herrian gertatzen dena. Orotara bost gutun igorri zen handik, haietarik biga - 11. eta 12.a, Maria Dihitxenak- kopia huts izanik. Martin Larralde Bastidagerreko jaunak sinatzen duena izan ezik, beste guztiak ber eskuak eginak lirateke. Esku kidetasun hori hainbat antzekotasunetan datza: 1) gutun-azaleko helbidearen forman; 2) kaligrafian; 3) dispositio grafikoan; 4) dataren formulan; 5) sartze formulan; eta 6) grafia sisteman. 2., 3. eta 4. irudietan ustezko D idazlariak (Senperekoak) idatzitako hiru gutunen hastapena konparatzen da.

Senpereko kasua ikusirik, pentsa liteke handiki bat dela bere gutuna egiazki idatzi duen bakarra, gaineratekoek idazlari baten zerbitzuak galdegin behar ukan dituztelarik. Baina halako ondoriorik ezin heda daiteke Le Dauphin corpusera, zinez kausitzen baititugu egoera desberdinak. Batetik, herri batzuetan ez da esku kidetasunik hautematen, eta bestetik ez dugu ikusten (ustez) idazlari batengana jotzen duten eta ez dutenen gizarte mailaren inguruko joera argirik. Adibidez, arrazoin askorengatik markagarria den 20. gutuna igorleak berak, Marie Darburu donibandarrak, idatzi zuen dudarik gabe. Luzeraz bigarren gutuna da, eta egileak ez bide zuen maila sozioekonomiko alturik; halaber, badirudi haren alaba neskato zegoela Louisbourgen. 
58

MANUEL PADILLA MOYANO

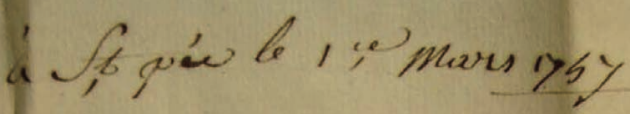

Pnel aléba noilew

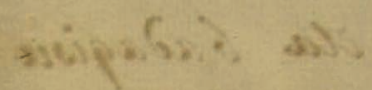

- jicatir dugre otrore yqusteco , ing omensicur.

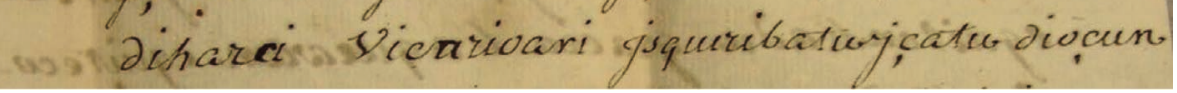

2. IRUDIA. 12. gutunaren xehetasuna. Maria Dihitx. Senpere, 1757/3/1.

a) 6 fied a y mars lyby

Sner Emeas

Shore dupe Cari wresentew Letra hunen jgorcew cler dembora berean guese berrien maseatios

3. IRUDIA. 16. gutunaren xehetasuna. Joannes de Matet, 1757/3/7.

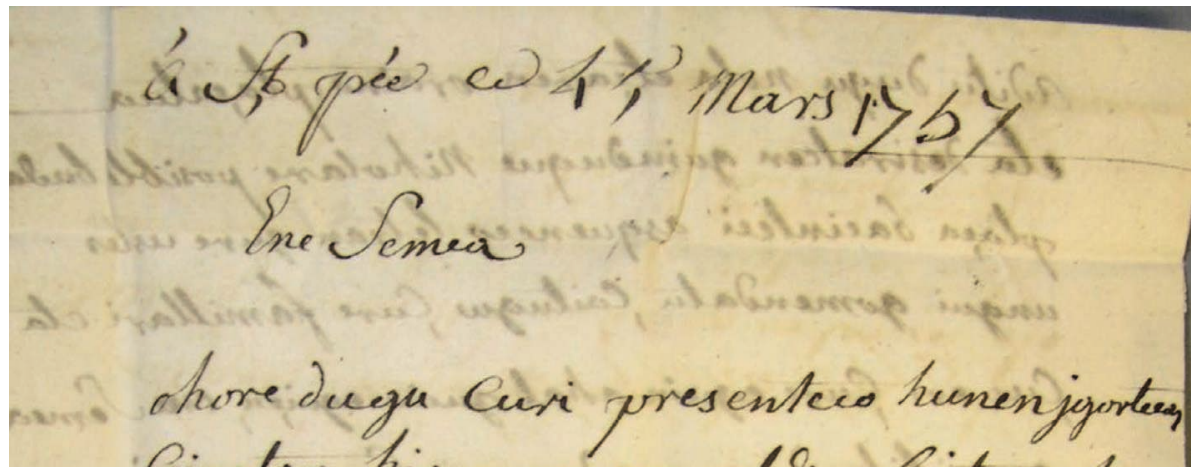
- Cinetar hirur garren albia baitugu hau

4. IRUDIA. 24. gutunaren xehetasuna. Betri d'Etcheberry, 1757/3/15. 
Baina nor ziren idazlari haiek? Haien lan isila oharkabean iragan da egundaino. Don Qochek, Etchegarayco Haurra Mariak edo Oyer Diratçabalek beren izena agerrarazi bazuten, 18 letratan ez dakigu nork idatzi zuen egiazki. Bi pertsonaia bereizteko dira: batetik, igorleari hurbil zitzaion norbait, eman dezagun familiako, adiskide edo hauzo bat, gutuna idazten ziona (lehen idazle deitu duguna); bestetik, eskola handiagoa zuen eta idazlari zerbitzuak manera profesionalean —erran nahi baita diru truk - errendatzen zituzkeen norbait (idazlari deitu duguna). Bigarren rol honetan aise imajinatzen ditugu herriko irakasle edo errejentak (notarioak ere, menturaz), zeinei idazlaritzak aukera bat emanen baitzien beren diru sarreren osatzeko. ${ }^{11}$

Euskararen historian deus guti dakigu idazlarien rolaz: orain arterainokoan ez zen haien gaineko frogarik, bederen fenomeno hedatu eta ohiko gisa. Baina Le Dauphin-eko euskal gutunek garbiki erakusten dute XVIII. mendeko Lapurdin populazioaren zati bat idazlarien zerbitzuez baliatzen zela. Guztiarekin ere anitz gutun, beharbada erdia baino gehiago, nork bere buruari diktatuz eginak izan ziren. Idazlarien aurkikuntzak, beraz, ez du kentzen garai hartan Iparraldeko euskal herrietako biztanleriaren zati handi bat alfabetatua izatea. Gehiago dena, ez dugu asumitzen gutun idaztea beste norbaiten esku uzten zutenak oro alfabetatugabeak izan litezen; izan ere, duela guti arte ikusi dugu gure artean nola pertsona batzuek, irakur eta idazteko gai izanik ere, nahiago zuten gaitasun handiagoko beste norbaitengana jo.

\subsection{Emazteen presentziaz, alfabetatzeaz}

Le Dauphin-eko lapurterazko gutunek informazio soziolinguistiko interesgarria eskaintzen digute. Genero parametroari doakionean, emaztekien proportzio altua azpimarkatzekoa da: esposek, alabek, amek edo arrebek gutunen \%60tik goiti sinatzen dute. Ehuneko horrek, hein batean, gutunen hartzaile gehienak gizon izate hutsari obedi liezaiokeen arren, ez genezake nehola ere gutiets: garaiko Lapurdiko emazteen alfabetatze gradu altuaren frogantza da, gizarte maila apaletan ere. ${ }^{12}$ Pentsa bedi beste gutun bilduma anitzetan zifrak oso bestelakoak izaten direla. Konparazio batentzat, Elspaß-ek XIX. mendeko germaniar herrialdeetako gizarte

11. III. milurtearen hastapenean ofizio horrek badirau beste herrialde batzuetan, nonbait denbora zaharri estekatua. Marokon ikusiak ditut jende xumeari dokumentuak idazten dizkioten idazlariak, arabieraz zein frantsesez, lehengo idazmakinak baliaturik. Gizon haiek lizentzia administratibo baten pean lan egiten dute, beren zerbitzuez araututako tarifen arabera pagatuak direla.

12. Emazteen pisu ohiz kanpokoak beste interpretazio bat duke, datu gehiagok bermatu beharrekoa bada ere. Le Dauphin ontziko dokumentazioan gutun gehienak frantsesez izkribatuak izatetik aise idoki daiteke $1757 \mathrm{ko}$ frantsesa aski sartua zela Lapurdin, kostaldean bederen. XVII. eta batez ere XVIII. mendean frantsesa euskal herrietan sartu ahala, euskarazko oinarrizko eskolatzea gizartearen maila apalenetara lerratuz joan zen (Oyharçabal 2001a eta 200lb). Testuinguru hartan frantsesaren ezagutza gizonengandik hedatzen hasi zela proposa dezakegu, goi ikasketak, administrazioaren karguak eta atzerriarekiko harremanak haien esku baitziren. Beraz, logikoa da pentsatzea frantses-euskara egoera diglosikoan emaztekiak gizonak baino luzazkiago egon zitezkeela elebakar. Gure ustez, horrek du azaltzen euskarazko gutun egile gehienak emazteak izatea, frantsesezkoekin alderantziz gertatzen denean. 
behe mailako jendeen gutunen aztertzeko diseinatu corpusean, emaztekiek idatziak ez dira bosten batera ere iristen. 6. TAULAk Le Dauphin gutuneriaren genero banaketa beste zenbait bildumatakoari konparatzen du. Bat batean, XVIII. mendeko Lapurdin emazte idazle multzo polit baten berri ustegabea dugu.

\begin{tabular}{|c|c|c|c|c|}
\hline \multicolumn{5}{|c|}{ 6. TAULA. Emazteen presentzia gutuneria corpusetan } \\
\hline & Emazte & Gizon & Orotara & Proportzioa \\
\hline \multicolumn{5}{|c|}{ Le Dauphin, euskaraz } \\
\hline Igorleak & 30 & 18 & 48 & $\% 62,5$ \\
\hline Hitzak & 7.417 & 2.968 & 10.385 & $\% 71,4$ \\
\hline \multicolumn{5}{|c|}{ Le Dauphin, frantses lagina } \\
\hline Igorleak & 11 & 41 & 52 & $\% 21$ \\
\hline \multicolumn{5}{|c|}{ Bearnes emigranteen gutunak (Bruneton-Governatori \& Moreux 1997) } \\
\hline Igorleak & 19 & 92 & 111 & $\% 17,1$ \\
\hline \multicolumn{5}{|c|}{ Nederlanderazko gutunen azpi-corpusak (Rutten $\&$ van der Wal 2013) } \\
\hline Igorleak & 95 & 311 & 406 & $\% 22,9$ \\
\hline Hitzak & 169.000 & 68.000 & 237.000 & $\% 28,7$ \\
\hline \multicolumn{5}{|c|}{ CEECE (Corpus of Early English Correspondence Extension)* } \\
\hline Igorleak & 94 & 214 & 308 & $\% 31$ \\
\hline Hitzak & 600.000 & 1.620 .000 & 2.220 .000 & $\% 27$ \\
\hline
\end{tabular}

Iduri luke XVIII. mendeko Ipar Euskal Herriko alfabetatze indizeak aski altuak izatea, gizonei begiratuz bederen: egungo Pirinio Atlantikoen departamenduan gizonkien \%70a alfabetatua zatekeen. ${ }^{13}$ Ikusi denez, Le Dauphineko igorle gehienak alfabetatuak ziren, kasu

13. 1786-1790 artean sinatzen zekiten gizonezkoen kopuruak, Frantziako Iparraldetik kanpo, soilik Pirinio Apaletan eta Alpe Garaietan gainditzen zuen \%70a (Grosperrin 1984: 159). Alfabetatze ehuneko altuenetakoak Pirinio Apaletakoak izatea, dudarik gabe Bearnogatik, ez da halabeharrezkoa. Bestalde, alfabetatze tasaren neurtzeko baliatzen den irizpidea, ezkontza agirietan sinatzen dakitenen proportzioan oinarritua, limurkorra da: batetik, argudia daiteke hainbat ezkontidek ozta-ozta zekikeela bere izenaren grafiatzen; bestetik, badakigu irakurmena zabalduago zegoela idazmena baino. Eztabaidagarritasunaz kontzient, historiagile batzuek sinaduren kalitatearen arabera jokatzea aholkatzen dute (Grosperrin 1984: 154). 
anitzetan populu xumeko kideak izanda ere. Oro har, beren desir, emozio eta izuak adierazten zituzten langile jendeak ditugu, Louisbourgen zeuden marinelen familiak eta adiskideak. Halako jende apala euskaraz izkribatzeko gai izateak Oyharçabalen tesiak (2001a; 2001b) bermatzen ditu: XVII. eta XVIII. mendeetan Akitaniako euskal herrietan bazen euskarazko alfabetatze sistema bat, frantsesa hedatu ahala gizartearen maila apalagoetara mugatuz joan zena. Euskarazko oinarrizko formakuntza hura, Belapeirek deitu "ororen eskoletan" (petites écoles) gauzatua, Eliza Katolikoari estuki lotua zen, xede kateketikoa nagusi izanik. Xumea eta oinarrizkoa izanik ere, halako euskarazko eskolatzeak kontraste bizia agerrarazten du Hegoaldeko egoerarekiko.

\subsection{Epistola gaiez}

Eskutitzen edukiaz denaz bezainbatean, kasik dokumentu orotan irakurtzen ahal dira Louisbourgera igortzen edo handik jasotzen diren objektuen zerrendak: kontserbak, edariak, arropak, zapatak eta antzekoak. Afera ekonomikoek ere halako lehentasuna dute, zorren kitatzea edo kanbio-letrak (letra chanjiac) arras ohikoak izanda:

Monsieur Haranchipik othoizten zaitu erraiteaz Samatxiko semeari eztuela horren letrarik batere izan, letra xanja bat izan duela horren partez, bainan ez dela oraino pagatua, hartzen baitu ungi goardatuko tuela, hartzeko esperantza orai baduela, ez dakiela zer gerthatuko den, Monsieur Beauvassin Arraxolakoak orai esperantza emaiten duela. Gauza bera erranen diozu Martin Canderatzi, Xotilen semeari, ez duela Monsieur Haranchipik errezibitu oraino dirurik, orai esparantzan dagoela $(25,2 \mathrm{v})$.

Migel Harismendik gaztiatu zarokun Granbitatik nola Milik eman ziotzan anaiari eta Belatzen semeari berrehun eta hirur hogoi libera, bainan gure semiak ez omen du errezebitu batere. Haren konpaniatik ethorri diren gizonek erran darokute, eta hor hartubak ditubelakoan, paga eztetzazun gaztiatzen darotzugu $(38,2 \mathrm{v})$.

Lapurdin utzi den negozio baten kontu errendatze zehatzaren aurkitzea ere posible da, edo zeharkako intentzio batez eginikako gaztigua, ondoko pasartean bezala:

Eta erranen darotzut zure ontasuna gibelat hari dela, zure ama andrea gai izan gabez. Eta azkeneko sasoina galdu du, harriaz porrokaturik. Hortik jujatuko duzu zure ahalaz lagundu behar duzula zure ama andrea, baldin nahi baduzu zure ontasuna konserbatua izan dadin, jauna ene iloba $(30,1 v)$.

Zazpi Urteko Gerla pizturik, orduko egoera nahasiarekiko aipamenak kasik gutun guztietan hatzemaiten dira:

Hemen ez da gerla hotsik baizin: baitugu herriko soldadoak Baionan, eta marinelak kortsuan dabiltza eta zerbait egiten dute, eta bertze zenbait Erregeren zerbitzuan dire (27, 2r).

Parti zaiztezte, ene maitiak, gerla handi baten aparantziak dire hemen. Angelesek hartu tuzte saratar zeinbait; orai ere guardia emozube zuben burubei $(47,1 v)$. 

du:

Jainko handiaren partez othoizten zaitut: ethor zakizkik etxerat. Eztut urrerik eta ez zilarrik galdetzen nik, zu baizik xutik nagolarik; hiratzen hari naiz zu ikusi naiz. Zu zare ene errezurtza guzia; othoizten zaitut ez nazazula akabaraz $(35,2$ r)

Hala ere, zuhurrenek egoera jabaldu arte pazientzia galdegiten dute:

Eta badakizu zenbat samurtasun duben ama batek bere umen aldera: desiratzen nuke hainitz zure ikustea, baldin Jainkoak egiten badu grazia bakearen egiteko. Eta badakizu, orobat, ume batek badubela obligazionea buraso baten obeditzeko. Beraz, hortarakotz othoitz egiten darotzut, neure ahal guziaz, gerla hunek dirabeino hor egoteaz, eta gero, bakea egiten den pontutik etxerat erretiratzeaz. Horra zer othoitz dudan zuri egiteko, eta desiratzen nuke entzuna banintz ene othoitzean $(11,2 v)$.

Igorleek maiz kontatzen dituzte beren penak eta estualdiak:

Ezta deus ere berririk hemen zuri markatzezo, gerla eta miseria baizen $(24,1 v)$

Badakizu ene estatuba zein pobrea den eta ene ahalak zein xumiak diren $(34,2 r)$.

Ene espos maitia, eztut faltatu nahi izan presenteko okhasione hau zuri aditzerat eman gabe ene estatubaren berria, zeinetan presentian hanitz miserable baikare ni eta alaba Goana Haurra xumia (38, 2r).

Xagriñak eta persekuzioneak izatu tut famillarekin, non hauzitan hari bainaiz. Egia da presentean aphur bat osasuna pixka bat badudala: sukhar lanjitak kitatu nau. Ene edaria da tizana, arno batere gabe. [...] Jenkoak izan dezala nitaz pietate $(26,2 \mathrm{r})$.

Azkenik, ez da falta gertakizun trukulentoen kontakizunik:

Eta zuri hemengo berrien adiarazteko, segur da aditu izan tuzula hemengo berri tristiak. Ehaile gaixoa preso harturik Jondone Laurendi egunian, 1755eko urthean, Parisat erama dute, Sabat dorreko zena norbaitek hiltzea dela medio, eta bi hilabete badu jendek darazatela bidean heldu dela libro bere etxerat, baiñan oraino ezta ageri gaixoa. Eta Ostaleriako premua, urthe berian Jondoni Jauni inguruan preso harturik, Toulonen da kondenaturik galeretarat sekulakotz, adiskideak ongi melaturik ez urkatzeko.. Eta diote denbora batez harekin ibili zen gizon bat, orobat, hura bezala jujamendu beraz kondenatua dela, Amikola ohiaren kolpatzea eta Seroraren leiho hausteko sujeta dela medio. Eta, itsasoan bezala, leihorrean ere fortunak arribatzen dire: Betrieneko jaun gaixoa, malobran hari dela, lur peza bat gainera eroririk lehertu izan da joan den udan, eta oren baten buruko hil konfesaturik (40, 2r-v). 


\section{Idaztearen esperientzia, epistola usantzak eta formulak}

\subsection{Ez osoki alfabetatuen idazteko esperientziaz}

Le Dauphin bildumako testuek igorleen alfabetatze maila eta idatz gaitasunaren aitzinean kokatzen gaituzte. Ikusi dugunez ( $\$ 2$ ), egungo ikerketan hizkuntzen historiari heltzeko ikuspegi berriak idazki pribatuak abantailatzen ditu, eta biziki gizartearen behe mailako lagunek eginikakoak. Maiz testu egile tipologia horrek ihes egiten dio alfabetatu vs. alfabetatu gabea dikotomia tradizionalari. Balio bezate Branca-Rosoff-en eta Schneider-en hitzek, Frantses Iraultza ondoko hiritarren testuen bilduma baten edizioaren aitzin-solasean:

Notre hypothèse de lecture refuse l'opposition trop simple entre lettrés et illettrés. Dans un pays comme la France où le travail de normalisation linguistique est très avancé les scripteurs se situent dans un système à trois termes: les illettrés n'écrivent pas du tout, les lettrés possèdent une langue réglée; mais entre les deux, il y a le groupe de ceux qui emploient une langue non conforme. Le jeu des préfixes pour désigner les hommes, néo-lettrés, semi-alphabétisés et surtout leur français, nonlettré, non-conventionnel, non-standard, non-légitime, indique la difficulté qui est encore la nôtre pour caractériser ces scripteurs et leurs formes d'écriture autrement qu'en termes de marginalité (Branca-Rosoff \& Schneider 1994: 9).

Van der Wal "barely literate" jendeaz mintzo da (2007), eta ez da falta kontzeptuari lotutako eufemismorik: "less than fully literate individuals" (Montgomery 1995: 33). Nolanahi ere den, XVIII. mendeko gizartean eskolatutakoen arteko anitz ez bide ziren idazteko gai. Gogoan ukan behar da garai hartako Europan irakurmena idazmena baino lehenago erakasten zela (Van der Wal \& Rutten 2013: 22); halaber, Frantziako ororen eskoletan lehen eta azken xedea dotrinaren erakaspena zen, idazmena bigarren maila batean geldituz (Grosperrin 1984). Pentsa bedi, gainera, idazteko tresneria (papera, lumak, tinta) kario zela, eta idazmenaren erakaspenak banakako arreta eskatzen zuela errejentaren aldetik. Horri gehitzen bazaio anitz gurasok ez zezaketela seme-alaben eskolatzea urte eskas batzuetarik haratago paga, haurrak lanean behar zirelako, logikoa da hainbatek alfabetatze partziala baizik ez zezaten erdiets.

Idazmena bereganatzen zutenenei begiratuz, Erregimen Zaharrean idazteko beharra ez zitzaiekeen maiz pausatuko, salbu eta ofizioz egin behar zutenei, jakina. Beraz, hizkuntza komunitate batean alfabetatze tasa ez ezik, idaztearen esperientzia ere desberdina izaten zen genero, gizarte maila eta garaiaren arabera (Rutten \& Van der Wal 2013). Gutunei dagokienean, ezin suposa dezakegu izkribatzen zutenek ere gutun idaztearen trebetasuna zeukatenik: generoa ikasi behar da. Finean, azken mendeetan populuko jendeek eskutitzak idatzi baldin badituzte, bortxaz dute egin: funtsez, familiakoak eta izaki maitatuen absentzian, emigrazioa edo gerlak zirela kausa. Beraz, "les lettres d'émigrés appartiennent au registre de l'écriture obligée" (Bruneton-Governatori \& Moreux 1997: 79). Emigrante eta soldaduen kasuan gutuneria zen familia eta komunitatearekiko estekaduraren gauzatzeko bide bakarra; hau da, gutunak nola edo hala izkribatu behar ziren, eta horretarako nork bere ahalaren arabera egiten zuen.

Bearnoko emigranteen gutunen corpusa aztertu ondoren, Bruneton-Governatori $\&$ Moreux ikertzaileek (1997) gutungintzaren eredu herrikoia deskribatu dute. Formari doakionean, gutunak hiruko eskema batean egituratzen dira: 1) hastapena (prélude); 2) erdiko atala; eta 3) bukaera. Preludio delakoak soilik manera bigarrendar batean bilatzen 
du captatio benevolentiae edo hartzailearen arreta. Haren funtzio nagusia gehiago litzateke idatzizko komunikazioaren eskakizun mailaren asetzea, igorleari konplexua gertatzen zaion eginbidea sinpletuz; horretarako formula jakin batzuen gainean eratzen da (§ 5.3). Erdiko atalak, aldiz, komunikazio askea ahalbidetzen du, eta erraitearen zailtasunak biltzen ditu. Gutunaren finitzeko, berriz ere epistola osagaietara itzultzen da, heste guti goiti-beheiti kodetu batekin —baina ez preludioa bezain finkatua-. Le Dauphin bildumako gutun haboroenak deskribatutako egiturari hertsatzen zaizkio.

Eskema hori ez da urrun Erdi Aroko ars dictaminis zelakoak Europan luzaz ezarri zuen egitura pentapartitotik, geroko eskuliburuek mende luzeetan jasotakoa: salutatio, captatio benevolentiae, narratio, petitio/dispositio eta conclusio. Maila sozio-kultural altuko gutun idazleek eredu herrikoia saihesten zuten. Hala ageri da bearnes emigranteen gutunerian, non gehien idazten duten 23 igorleen artean bakarra urruntzen baita eskema herrikoitik, eta adierazgarriena da igorle hori dela, aldi berean, frantses estandarra baliatzen duen bakarra. Jakina, deskribatutako moldea ez zen bakarrik bearnesen artean baliatzen:

Si ce modèle est aussi connu, bien que rejeté, c'est évidemment qu'il n'est pas spécifique aux Béarnais, émigrés ou soldats. C'est lui que suivent, avec des variantes régionales, d'autres scripteurs populaires, eux aussi migrants ou soldats à la même époque: Auvergnats, Creusois, Alsaciens. Il est présent dans les lettres de poilus et il semble actuellement toujours vivant chez les Tsiganes, comme le montrent des lettres aimablement communiquées par P. Williams (Bruneton-Governatori \& Moreux 1997: 99).

\subsection{Bi lapurtarren idazmoldeak: Mari Darburu eta Francha Barrere}

Maila jasoko igorle bakan batzuez apart, barietate estandarraren ezak Le Dauphin bildumako gutun egile bakoitzari bere herriko mintzora jo eragiten dio. Ber arrazoinarengatik —eta idazlarien parte hartzeak ekar litzakeen ondorioetarik landa (ikus \& 4.2)_, kasik gutun bederak bere grafia arauak ditu, aldakortasun ezin oparoagoa lekukotuz. Etsenplutako, lapurteraren idatzizko tradizioan [k] hotsa, oro har, $<\mathrm{c}>$ gisa grafiatzen da $a, o, u$ aitzin eta $<q u>e, i$ aitzin; <k> ezohiko grafema da. Horretaz gain, 1757ko gutunerian <qu> $a, o$ aitzin ere gerta daiteke (oquasione 2, horquo 44), <c>e, i aitzin (nuce 36a, cintal 29), <cc> (occasionias 37; kasu honetan [kh] edota grafia etimologikoa izan liteke, baina bakarra da gutunean), $<\mathrm{ch}>$ (eschribaceco 6), <q> zein-nahi bokalekin (oqasione 42, liteqe 26, iguriqiric 26, Jainqo 35, daroqu 38), <k> ere nehoiz ageri dela (Katuruq 33, Katalin 31). Antzeko aldakortasuna aurki daiteke txistukarien eta hots sabaikarituen sailetan. Batzuetan gutun egileek formula ezezagunak erakusten dituzte: <enez semaiz> 'ene seme' 48 (dudarik gabe frantsesaren grafiagatik); <gaiñgñeraco $>34$.

Bildumako gutun luzeenak, biak emaztekiek eginak, idazteko ohitura diferenteez mintzo zaizkigu. Bata da Mari Darburu donibandarrak sinatzen duena (20. zenbakia, 793 hitz), eta bestea Francha Barrere anderearena (49. zenbakia, 879 hitz). Bere alabari noka moldean idazten dion gutunean, Darbururen lapurtera kasik entzuten ahal da. Ezaugarri fonologiko nabarienak baizik ez ditugu aipatuko: 1) bokal altuen ondoko epentesien betetze maila nabaria da: \%100a eta \%89a, hurrenez hurren, $u$ ondoko [ $\beta$ ] eta $i$ ondoko [j]ren txertatzeentzat; 2) u-ren kontsonantizazioa (hauela, haurraren, Gana Haurra > habela, habraren, Ganabra); 3) hitz bukaerako herskarien bat etortzea (Baionatit, etxetit, denboratit, geroztit, gogotit, pezatit, 
zergatit, sokolotat, Bisentet, Marilantat); 4) $r t>s t$ bilakabidea (sartuba, ardit bat > sastuba, asdipat); 5) maileguen egokitzapen fonologikoak (master masetereari); 6) ahoskeraren araberako bestelako grafiak (bere partetik > bere bartetit); 7) molde guztietako erortze eta uzkurdurak (aditurik, ditinat, Santa Barbarako > aiturik, tinat, Santabarrako). Hala eta guztiz, Mari Darbururen grafia sistemak koherentzia erakusten du, idazteko ohitura zuelako seinale -mintzo bezala idatzi ere- Horrela, txistukari afrikatuen adierazpen sistematikoa egiten duten igorle hautatuen multzoan kokatzen da, adierazpen hori defektiboa bada ere, ez baitu afrikazio puntua bereziten: gurexat, cuxaturic, exetit. Ondoan haren gutunaren lehen atalaren transkripzioa dakargu: ${ }^{14}$

Donibanen eguina marxoanen 13

/ Ene haur maitea estinat faltatu nahi hiri / ene berijac marcatu gabe cenac eraten baitun / estunala aspaldijon gure beriric jcatu hanbat $/ 5$ gastoago gurexat nic eguin dausquinat beti / unsi gusietan letrac eta hic es jsatu estun / beras ene faltaric egori dinat bat lanxecanetu ${ }^{\text {in }}$ / bersea hire cusina defuntubarequin cenac etori / baixen miselequin bajonarat gasoa eta egori / ${ }^{10}$ naunan harequin berajnquin mantalina angelet / acoa ungi fina bere eribana eta siricubarequin / cenac hire matantac churunecoac cuxan sartu / omen baixuben eta berce bi letra patineneco / siburuco premubarequin cenac egun angeletaran $/{ }^{15}$ baita gasoa Ene haur maitea badin hilhunen / hogoy eta sejean exetit partitu hinxela egundano / hirur urte egundano estinat jsatu oren laurden / baten erepausuric basaquinat gusijac ene / faltat direla cenac ene becatubac handijac $/ 20$ baitire banan esparanxa dinat jeancoac / misericordia jsanen dubela nitas cergatit / ene uste gusijan ungi harcen tinat eta / adixen tugunaren arabera estela posible / salbaxea hemen non estugun becatuba $/ 25$ purgaxen beras esparanxan nijagon / jencoac estausquidala bi pena emanen

Kontatzeko duen guztiaren askitasunez adierazteko gauza izan arren, Mari Darburuk bere idazmenaren gabeziak aipatzen ditu. Post scriptum gisara, dataren zifratan emateko ezintasuna aitortzen du: "ene haur maitea, enaquinan nola eman mila saspi ehunac" (20, 3v).

Oso bestelakoa da Francha Barrere anderearen kasua, emazteki honek hizkuntza idatziaren errejistro gorenen ezagutza erakusten baitu. Sintaxiaren konplexutasunak zein baliabide erretoriko eta estilistikoek aszetika liburuen irakurtzea salatzen dukete, eta decorum kaligrafikoak idazteko ohitura. Hona hemen senar zapatagileari izkribatzen dion gutunaren lehen partea:

14. Atal honetan testuen bertsio paleografikoa lehenetsi dugu. Gure interpretazioa, grafia eguneratuan, edizioaren B. bertsioan irakur daiteke. Mari Darbururen nahiz Francha Barrereren gutunen faksimileak liburu honen akabantzan ikus daitezke. 
Ene Espoz maitia =

/ Baliatçen nais Presenteco Comoitate hunaz Çuri / satifazione emateco Çenbat consolasione eta boscariorequin / Causitcen naisen aditçias Çure ossasunaren $/ 5$ berriac seiña satifatu bainaute çure ganic ereçibitu / ditudan bortz Letretec, arosoiñeiquin diot haiñitz Conzolaziones / bethia Causitçen naizela Çure ossasuna onaren / berrien aditçia Çeren presentian Çure Presençiaz / Landan ez bainuen desiratçen bertçe ontaçunic eta $/{ }^{10}$ aberastasunic baizen çure ossasunaren satifazionias / bada nic ere satifatçen Çaitut gurias = seña baitugu / haiñitz perfecta Jaincoary esquer eta hala desiratçen / nuque ene bihotz guçias çuria hala balix eta / horen conserbasioniaren intençionetara Jaincoa / ${ }^{15}$ Erequedituco dut eguin ahal deçaquedan molde diferent / Guçies diçula Lehenic ossasuna izpirituala eta guero / temporala bay diot / Lehenic izpirituala eta Guero temporala Çergatic / hura gabe ez baicare arbola idor fruituric ecarsen ${ }^{20}$ ez duen bat baizen seiña arbola fruituric ecarsen / ez duena Condenatua baita picatçerat eta Çurat / hartiquitçerat

eta idia Justu huntas seguratçen Gaitu $<49.2 v>$ Jesus Christoc bere Evangeliguan; Comprendiarasten / dauqularic hitz Labur hautas gu garela arbola hura/eta es baitugu Fruitu onac ecartçen Condenatuac / izaren garela; eta nola Fruitu on-hequin ecarseco /5 ez-baitugu deuseure inportantago; ossasuna izpirituala / baiño hargatic desiratçen dautçut Lehenic eta / Guçien gaiñetic; ossasuna ezin asqui presa daitequen / hura; seiña gabe ez baicare deusic nic baiño / hobequi daquiçun beçala gauça guçiac harequin baditugula / ${ }^{10} \mathrm{ez}$ bedi beras seculan aparta gure ganic guretçat / haiñ inportant de[n] perla presiatu hura biçia / galduco badugu ere haren sustengutan eta çhede horiec / gure bihotzetan Vngui fincatuac baitugu, seguratuac / izan bihar dugu temporalian ere nola ez daquigula $/ 15$ abantçatuaz garen garela eta ezparantça dut eguia / inportant horiec Çure bihotzian hobequi imprimatuac / eta seguituac direla enian nic baiño =

Ebanjelioaren aipua azpimarkatu nahi nuke. Barrerek honakoa dakar: hura gabe ez baicare arbola idor fruituric ecarsen ez duen bat baizen, seiña arbola fruituric ecarsen ez duena condenatua baita picatçerat eta çurat hartiquitçerat; pasarte horrek $M t ~ 3,10$ bersetera igortzen du. Sintaxiak Leizarragaren itzulpenarena gogorarazten du, erlatibo postnominala baliaturik: Bada ia aizkora arboren errora ezarria da: beraz arbore fruktu onik egiten eztuen guzia pikatzen da eta sura egoizten. Aldiz, beraskoiztarraren egoitzi gabe Barrerek hartiki aditza hautatzen du, Haranederrek bezala: Jadan ezen haizkora arruntzatua da arbolaren erroaren gaiñean. Hala, beraz, fruitu onik ekhartzen ez duken arbola guzia izanen da ebakia eta surat arthikia. Ez dugu sujeritzen gutun egile honek bata ala bestea irakurria zuenik; gainera, kontzient gara Haranederren itzulpena luzaz egon zela argitara eman gabe. Lapurdiko emazte kulto honek zein testuak irakur zitzakeen idurikatzeak jakin-mina pizten digu.

Beste pasarte batean Francha Barrerek bere semearen eskolatzeaz mintzo da: "Joanis galant vngui eraqursen eta mesa laguntçen ikasiric escribatçen hari da, seiña letra hau hari sinarasten diot, eta nauçia haiñitz content du" $(49,3 r) .{ }^{15}$ Gutunaren eranskin gisa, senarrak

15. Pierre Etchegaray azkaindarrak ere halakorik aipatzen du: "Semea Baionan dugu eskolan eta osasuna du, eta guk ere osasuna dugu famila guztiak" (36b). 
Lapurdin utzi duen negozioaren kontuak errendatzen ditu Barrerek: "Memorio hau egortçen dautçut çuri satifaçione emateco oray arteraiñoco gure eguitecoac nola duazen edo nola guelditçen diren" (49, 4r). Hartzekodun eta zordunekiko egoera zehazten du, zenbakiak behar bezala emanik. Guztiagatik, idoki daiteke Barrere andereak idaztearen esperientzia zuela, bere egunerokotasunean ongi errotua ere.

\subsection{Lapurterazko epistola usantzak eta tradizio paneuroparra}

Hiruko eskemarekin batean (§ 5.1), gutungintza herrikoiaren ezaugarri nagusia formulen erabilera da. Oro har, honakoa har dezakegu eduki formulistikotzat: "A sequence, continuous or discontinuous, of words or other elements, which is, or appears to be, prefabricated: that is, stored and retrieved whole from memory at the time of use, rather than being subject to generation or analysis by the language grammar" (Wray 2005: 9). Formulen azterketan sartu aitzin, kontsidera dezagun 35. gutuna, ama batek bere semeari igorria, eta ustez idazlari batek egina: A eskua, Getariakoa (ikus 5. TAULA). Letra etzanez perpaus purki formulistikoak markatzen ditugu: [1] data, [2] idekitze formula, [3] osagarriaren formula, [4] "agur samurra", [5] heste formula, [6] sinadura aitzinekoa, eta [7] sinadura. Orotara, 101 hitzetarik 66 egitura "aurrefabrikatu" gisa sailkatzeko dira, eta menturaz gehiago:

\section{[1] fait aguethary cé 22 marz 1757}

[2] Enne seme Maitea Estut faltatu nay jçatu presenteqo oqasione huntan çury By Lero Esqribatu gabe [3] Eta Cury Ene ossasuna Beria gastiatu gabe çeinetan Baita ona jainqoary Esquer desiraxen nuque çurea halla Balix Çure conpaniarequin Batean

[4] Enne seme Maitea sallutaxen Çaitut Bihox Çamur Batequin jainqo handiaren partes othoisten Çaitut Ethor çaquisquiq Etçherat Estut vrreriq Eta Es çilariq galdexen niq Çu baiçiq çhutiq nagollariq hiraxen hary nais cu jqusi nais çu çare Enne Erreçurxa gusia othoisten Çaitut Es naçaçula aqabaras

[5] Estut presentean Çury Çer gastia Baiçiq naicella [6] Cure Cerbixari Cure ama orai Eta Bethiere [7] qatarine desclaus

Oroz gainetik, formulen pisua hastapenean sumatzen da. Le Dauphin-en denborakoak diren —baina ez bakarrik - bearnes emigranteen eskutitzen preludioek egitura finkoak agertzen dituzte. Preludioaren hastapenean bi aukera dira: (1a) edo (1b), horren bukaeran antzeko maneran gauzatuz (1c). Erdiko atal askearen ondoren, gutunaren akabantzak berriz ere formulak eskatzen ditu; (1d) eta (1e) dira ohikoenak (Bruneton-Governatori \& Moreux 1997: 83):

(1a) Je vous écris ces quelques lignes pour vous donner de mes nouvelles (qui sont assez bonnes pour le moment).

(1b) Je réponds à ta lettre qui m'a fait un grand plaisir de savoir que vous jouissez d'une parfaite santé. 
(1c) Je vous dirai que je me porte bien et je désire que la présente vous trouve de même.

(1d) Compliments à tous nos parents.

(le) Rien plus à vous dire pour le moment.

Mutatis mutandi, lapurterazko gutunen igorleek ber moldeak baliatzen dituzte. Hona hemen formula erabilienak:

(2a) Hartzen dut libertate zuri bi lerroren eskribatzeko (ene osasunaren berria gaztigatzeko / ene berrien gaztigatzeko).

(2b) Ez dut faltatu nahi izan presenteko okhasione hau zuri aditzerat eman gabe...

(2c) Familia guzia kausitzen gara osasun perfeit batean, eta desiratzen nuke zurea ere hala balitz (desiratzen nuke presenteko honek hala aurki bazintza).

(2d) X-k goraintzi (mila-)mila / goraintzi X-rentzat.

(2e) Ez dut presentean zuri zer gaztiga.

(2f) Gelditzen naiz zure ama fidela eta obedienta / zure zerbitzari umila.

(1) eta (2) etsenplu sorten arteko kidetasunak nabarmenak dira; behetiago itzuliko gara afera honetara. Preludioaren begien bistako funtzioez gain - eginbidearen sinpletzea, komunikazioaren ezartzea-, haren izaera kodetuak beste zerbait eskain ziezaiokeen igorleari: "La complexité syntaxique donne au prélude une solennité qui rappelle les textes dministratifs et notariaux et illustre bien la fonction d'hommage quasi officielle de la lettre d'émigré" (ibid. 89). Konplexutasun hori aipatua izan da beste tradizioetan: "The elaborate phrases on health, with the various subordinate formulae" (van der Wal \& Rutten 2013: 25). Jakina, Le Dauphin bilduma ere preludioaren konplexutasun sintaktikoaren lekuko da:

Donibanen marz 22an 1757

Nere seme maitia

presenteco occasionias baliatuba jsan nadintçat hartu dut moment bat sury by Lerro hauquietan Gure ossassuna onas partalier eguiteco deliberacionia desiratcen nuque suria presentecoan Gauça berian Causi baleça [...]. Gana Haurra de Fumat (37, 2r).

A Saint Jean de Luz le 24. mars 1757

Neuré semé maitia

Satisfatuba Jçan ondoan çuc asquén Eguin letras nolha sindoasen Louisbourquerat partitcerat occationnia favorable atcemanic Escribatcen darosquitçut Bi lerro hauc cury satisfatcerat Emaiteco neuré ossasuna çuré ahaide guciequin batian ceinac Desiratcen Bainuqué presenteco huneq hala aurqhy Bacintça [...]. Machume Basterreche (41, 2r).

Rutten \& Van der Wal-ek (2012) funtzio pragmatikoen araberako sailkapena proposatzen dute epistola formulentzat: a) formula testu ezarleak ("text constitutive"); b) formula intersubjektiboak, igorle eta hartzailearen arteko harremanei doazkienak (osagarria, agurrak, 
kontaktua); eta 3) formula giristinoak. Halere, maiz gertatzen da funtzio hauek formula batean gainjartzen direla, sailkatzeko luketen balioa lausotuz. Presenteko lanaz den bezainbatean, ez dugu sailkapen zehatzik baliatzen. Le Dauphin-en maizen errepikatzen diren egituren aztertzera mugatu gara, gutunaren zein ataletan agertzen diren arabera.

Uste dugu formulen funtzio nagusia igorleari halako euskarri baten eskaintzea zatekeela. Egitura horiei esker, gutunak idazten halako esperientzia eta ohitura ahulago zutenak aiseago lot zekizkiokeen idazteari. Izan ere, erakutsi izan da jada Le Dauphin-en dokumentazioaren garaian epistola formulen maiztasuna gizarte mailarekiko alderantzizko proportzioan zihoala (Rutten \& van der Wal 2013). Lapurterazko corpusari erreparatuz, adierazgarria da igorle trebatuenak izatea egitura "aurrefabrikatuetarik" gehien urruntzen direnak: hala Mari Darburuk eta Francha Barrerek (ikus § 5.2) nola Haraneder apezak (39. gutuna, Urruñatik) fazoin libreago batez idazten dute.

Lapurterazko gutunetan oso deigarria da zenbait epistola formulen erabilpen arras hedatua. Maiztasunari erremarkatuz gero, gutun gehienek agertzen dituzte egitura ohikoenak, 7. TAULAk erakusten duenez:

\begin{tabular}{|c|l|l|l|}
\hline 7. TAULA. Epistola formulen erabilpena Le Dauphin-en \\
\hline & Bai & Ez & \\
\hline Data, zeinetarik & 48 & 2 & $\% 96$ \\
\hline ... euskaraz & 25 & & \\
\hline$\ldots$ frantsesez & 23 & & \\
\hline Idekitze formulak (2a, 2b, 3a) & 36 & 14 & $\% 72$ \\
\hline Osagarriaren formula (2c) & 41 & 9 & $\% 82$ \\
\hline Sinadura aitzinekoak: (2f, 3d) & 48 & 2 & $\% 96$ \\
\hline
\end{tabular}

Hauetaz gain, Le Dauphin bilduman beste formulak ere aurkitzen ahal dira:

(3a) Ohore dugu zuri presenteko letra hunen igortzeko eta denbora berean gure berrien markatzeko

(3b) Salutatzen zaitut bihotz samur batekin.

(3c) Erranen dautzut...

(3d) Zure ama, orai eta betiere / bizi naizeno.

Gorago ikusi bezala, XVIII. mendeko bearnes eta lapurtar emigranteen gutunek ber eredua segitzen dute; oroit (1) eta (2) adibide multzoen bat etortzeak. Iraultza eta Inperioaren garaikoak diren soldado bearnesen gutunetan ere (Staes 1979-1992) kidetasun nabarmenak atzeman daitezke. Idekitze eta osagarriaren formulak Le Dauphin bilduman kausitu ditugun 
bertsuak dira. Ondoan Dominique Goute-ren arrebaren gutunaren pasarte bat -baina Le Dauphin-eko beste hainbat ekar litezke— eta bi soldadu bearnesenak transkribatzen dira:

\section{Bidartten Egina martçoaren 261757}

Ene anaia maitea hartçen dut libertad çuri bi lerroren Escribatcequo Eta famlilaquo berrien curi aditçerat Ematequo ossasuna dugu jainquoari Esquer ceinetan Desiratcen baiquinduque curea halla ballis $(44,2 r)$.

Fait à l'ile de Porquerole le 8 septembre 1811.

Mon tres cher frere, je l'onur de vous ecrire se dus mots de lettre pour vous faire sçavoir l'etat de ma santé, laquel est bonne Dieu mersi. Je sçouhete que la votre se trouve de meme en compagnie de ma mere et de mes freres et de mes paren et de mes amis; je vous fait bien de complimens a tout [...]. Jean Couartou (Staes 1979).

Telsit le 21 auoust an 1812 an Paulogne, frontiere de Russie.

Mon cher ami pere et frere, set avec un sensible plesir que ge j'onneur de vous ecrire dus lignes pour vos aprandre l'etat de ma santé [...]. Guichot (Staes 1979).

Akitaniako hauzo izanik, ez da estonagarri bearnes eta lapurtar emigranteak ber epistola tradizioaren partalier izatea, hizkuntza desberdinetan bada ere. Formula hauek, gisa guztiz, frantsesaren bitartez sartu ziren lapurteran. Horrela gertatzen bide da diglosia egoeretan, non material formulistikoa goi barietatetik behe barietatera iragaiten ohi baita (Häcker 2010). Le Dauphin bildumari doakionean, kasu batzuetan nabariak dira frantsesezko moldeak. Begien bistakoen bat da zure zerbitzari umila / hunblea / obedienta (cf. votre très humble / obéissant serviteur), euskarazko gutun zaharrenetarik lekukotua. ${ }^{16}$ Baina bestelakoak ere: "eguiten dausquitçute bere conplimenduac" $(39,2 \mathrm{r}$ ) (cf. ils vous font leurs compliments); "çure semea ungui da, bere errespetuez seguratcen çaitu" (5, 2r) (cf. il vous assure de ses respects). Libertate dakarren idekitze formula, Le Dauphin-en hain errepikatua, Baionako judu batek idatzitako frantses gutun batean kausitu dugu:

Mon très cher pére de mon âme,

Je prends la liberté de vous écrire ces deux lignes, parce que je considère qu'à la fin les pitiés d'un père sont fort grandes, comme on dit, un père l'est pour cent enfants. [...] Signé: Abraham Roblès. Bayonne, le 15 janvier 1742 (Hidiroglou 2003: 111).

Baina ez da bakarrik frantsesa bezalako hizkuntza azkar batek bere eraginpeko komunitateen usantzak molda zitzakeela: badakigu garaiko Europan epistola formulek

16. Horrela aurkitzen dugu Bertrand d'Etxauzen letran (1584): "Çure anaye leala eta hun desiraçen dudana eta cerbuçu egitera obedien datena ni nuqueçu", eta nabariago Simancaseko espioitza gutunetan (1598): "geldizen naizela beti bezala serbizary homblea", edo "zure serbizary humbleac adieu esatendizu". 
hizkuntzen mugak gainditzen zituztela. Etsenplutako, konpara bitez orain arteko egiturak, lapurterazko zein frantsesezkoak, ingelesezko baliokide honekin: I now take the Oppertunity of wrighting these few lines to You hoping the will find you all in Good health as I am at present thanks be to God for it (Austin 2000: 53). Bruneton-Governatori \& Moreux-ek atzeman dute ingeles, eskoziar, irlandar, aleman, aleman-suitzar, italiar-suitzar eta poloniar emigranteen gutunek formula komunak dituztela (1997: 100). Geroztik, kasik identikoak diren formulak identifikatu dira irlandar, holandes, germaniar eta daniar emigranteen gutunetan (Elspaß 2012b: 53), horietako batzuk finlandieraz ere (Laitinen \& Nordlund 2012: 69).

Froga horiek ikusirik, Elspaß-ek bere buruari galdegiten dio "whether there existed something like a central European stock of letter writing formulae and how they could have evolved or how they were transmitted into the different languages" (2012b: 60). Era berean, Van der Wal \& Rutten-ek atzeman dute XVII. eta XVIII. mendeetako nederlanderazko gutun pribatuetako formulek antz harrigarria erakusten dutela beste hizkuntz eremuetakoekiko (2013), eta horrek bide eman die proposatzeko "a pervasive pan-European tradition of letterwriting" (Rutten \& Van der Wal 2013: 52). Epistola formulez haratago, "les corpus des lettres d'émigrés [...] mettent en évidence une internationale épistolaire inattendue", egituran eta gaietan ere hautematen dena (Bruneton-Governatori \& Moreux 1997: 100). Eta urrunago joanez:

Ces convergences partielles sont intrigantes. En tout cas, on ne peut qu'être frappé par les ressemblances entre les lettres des émigrés européens et celles qu'envoyaient à leurs familles les soldats grecs à l'epoque hellénistique, selon la description qu'en fait Koskenniemi [...]: pauvres en informations, répétant sans complexe des formules stéréotypées, elles se contentaient de manifester par elles-mêmes la permanence du lien entre le soldat et sa communauté (BrunetonGovernatori \& Moreux 1997: 101).

\subsection{Epistola usantzen transmisioaz}

Galdera pausatzen da: Lapurdiko maila apaleko jende haiek nola eta nondik ikasten zituzten epistola formulak? Lehen arraposta bat izan daiteke gutunen izkribatzeko ohitzak ororen eskoletan transmititzen zirela, oinarrizko eskolatze baten eduki gisa. Baina nekez idurikatzen dugu eskola xume haietan gutunen idazteko eskulibururik erabiltzen zenik, irakaskintzaren helburuen artean idaztea sekundarioa baitzen. Pentsatu behar da, halaber, gizarteko maila apaleko familien etxeetan eta ororen eskoletan izan zitezkeen liburu bakanak dotrinari lotuak 
baizik ez ziratekeela. ${ }^{17}$ XVIII. mendean liburu edukitzeaz dugun informazioagatik halakoa bide zen egoera Europan gaindi:

The increase of the production of vernacular reading materials, however, does not imply that any member of late-eighteenth-century society read more books or spent more time reading than any member of seventeenth-century society. The written culture was socially stratified. Stein [...] notes that in the West of France in the first half of the eighteenth century no less than a third of all estate inventories includes books titles, but most of these were found in the inventories of writers, scholars, lawyers, clergymen and nobles, and much less among merchants and labourers. [...] De Kruif estimates that in the eighteenth-century 39\% of the population of The Hague did not possess any books, and another 27\% no more than five books (Rutten \& van der Wal 2013: 47-48).

Afera ez datza soilik liburuen balizko erabilpenean. Soldaduen korrespondentziaren kari, Branca-Rosoff-ek epistola formulen transmisioaren arazoa seinalatzen du, liburuez bestelako aukerarik iradokitzen. Eskuliburuetan peitu izateaz gain, "il est impossible d'imaginer un apprentissage de la forme "fautive » [...]. Leur emploi très répandu nous renvoie à l'idée qu'il existe des systèmes d'apprentissage du style écrit qui échappent aux manuels scolaires" (1990: 22).

Gutun idazten ikasteko, van der Wal \& Rutten-ek hiru esparru posible dakuste: eskola, etxea eta zenbait ofizioren aprendizgoa (2013: 22). Aipatu esparruetan izan zitezkeen liburuak goiti-beheiti, garaiko nederlanderazko epistola eskuliburuei begiratu die. Horien artean bi lan mota bereizi behar da: batetik elite manuals, eta bestetik irakurlego xumeago bati zuzendutako liburuskak (ibid. 28). Lehenbizikoek ez dute Letters as Loot corpusean ageri diren formulekiko den mendreneko kointzidentziarik agertzen, eta bigarrenek soilik hein ttipi batean. Gehiago dena, maiztasun handieneko formula batzuk ez dira nehongo liburutan aurkitzen. Espero izatekoa da maila apaleko jendeak ez edatea elite manuals haietarik; ifrentzuan, liburu jaso haien egileek ihes egiten zuten populu xehearen ohitzetarik, hau bezalako jujamenduak eginez:

On doit dire dans une lettre les choses comme elles se présentent à l'esprit, sans se permettre jamais des mots impropres, des phrases triviales, des proverbes populaires. Par exemple, ces expressions : je vous écris ces lignes ou ces deux lignes. Je prends la liberté de vous écrire pour m'informer de l'état de votre santé, etc., sont non pas du style simple, mais du style bas : le ton de

17. Oloroeko elizbarrutiko ororen eskolak arautzeko egin liburuxkan, Montillet apezpikuak datu interesgarri batzuk eskaintzen ditu. "De la lecture" artikulutik atera dugun pasarteak klarki ezartzen du bertan erabili beharreko liburu mota:

Le Maître ayant ainsi divisé son Ecole observera ce qui suit. [...] Qu'ils ayent tous le même Livre \& un Livre de piété, tel que les figures de la Bible de Royaumont, ou autre, de la même impression, s'il se peut, \& qu'ils ayent tous la même leçon. [...] Les choses ainsi disposées le Maître ayant à la main le livre que les enfans lisent, donne un signal pour faire lever toute la bande [...] (Montillet $1740: 16$ ). 
la bonne compagnie ne les souffre point (Martin, 1836: 106).

Garaiko eskuliburuak gutungintza herrikoiaren iturri gisa bazterturik, beste aukera xerkatu behar dugu. Menturaz emulazio bat idurikatu behar den, kopien bidez: "It is more likely that they adopted such formulae from model letters that were used in schools or which they found at home" (Elspaß 2012b: 55). Gutungintza paneuroparraren eredu herrikoiak iraun du, "transmis sans doute par la lecture et la mémorisation de lettres, rendant possibles des variations et recréations individuelles" (Bruneton-Governatori \& Moreux 1997: 101-102). Suomi emigranteen gutunak direla eta, Laitinen $\&$ Nordlund-ek berriki proposatu dute epistola formulak gehiago ikasten ziratekeela entzunez, irakurriz baino (2012: 73), eta McCafferty-ren ustetan gutunak mintzatuak izateko kontzebituak izan zitezkeen (komunikazio pertsonala).

\section{Ondorioak}

Lan honetan Le Dauphin itsasontziko lapurterazko gutunek (1757) euskal ikasketei pausatzen dizkieten aukerak eta erronkak iruzkindu ditugu, nazioarteko epistolografian baliatzen diren hurbiltze teoriko eta metodologikoak —batez ere soziolinguistika historikoarenak- euskal ikasketetara ekarri nahiz.

Hizkuntzen historiarentzat duten balioagatik, eta aldi berean beren eskasiagatik, egungo ikerkuntzak dokumentu pribatuak pribilejiatzen ditu, bereziki egile ez osoki alfabetatuen egodokumentuak. Horrek hanbatenaz balio handiago du euskararentzat, lekukotasun mota horren abantailak ez baitira esploratu. Euskararen corpusean hobekien ordezkatutako euskalkia lapurtera izanda, lekukotasunen homogeneotasunak — funtsez testu erlijioso inprimatuakmintzo honen historiako zenbait fenomeno estali duke (Padilla-Moyano 2015; Urgell 2013). Beste hizkuntzetako gutuneria corpusekin gertatu bezala (van der Wal, Rutten \& Simons 2012), Le Dauphin bildumak, bere heinean, hizkuntzaren historiaren hutsune horiek bete ditzake ("fill gaps").

Le Dauphin-eko lapurterazko gutunek XVII. eta XVIII. mendeetako Iparraldeko egoera soziolinguistikoaz proposatu dena (Oyharçabal 2001a; 2001b) berresten dute. Aldiz, garrantzizko bi fenomeno ezagutarazten digute. Batetik, emazteek igorleen artean duten pisu handia, menturaz, uste genuen baino alfabetatze femenino hedatuago batez mintzo da. Bestetik, gutunen erkatzetik behin-behineko datuak idokirik, lehenbizikoz jakiten dugu idazlarien berri. Euskararen historian orain arte ezezaguna zen pertsonaia honetaz dena dago erraiteke.

Diskurtsoaren mailan, izaera apaleko gutunek argia eman dezakete kulturaren historian. Erakutsi izan da Europako hizkuntzetako jende guti alfabetatuen gutunetan bat etortze nabarmenak gertatzen direla egitura, forma eta edukian. Epistola formuletan ikusi dugunez, kointzidentzia horiek ez dira halabeharrezkoak. Lapurtar gutun egileen idatz moldeak azterturik, eta Europako beste hizkuntzetako gutuneria corpusen ikerketen ondorioak gogoan, ez da dudarik Le Dauphin bildumako testuak gutungintza herrikoi paneuropar izendatu dugun tradizioan kokatzeko direla. Etorkizunean Le Dauphin itsasontziak karreiatzen zituen fransesezko gutunak, Londresen daudenak, ikertu beharko dira. Lapurterazko eta frantsesezko gutun multzoen konparaziotik interes biziko ondorio soziolinguistikoak atera litezke.

Orain arte egin dena ahantzi gabe (nabarmenki Pikabea 1993 eta Mujika 2002), 
lapurteraren gainean eraiki zen literatur hizkuntzak ikerketa sakonagoa eskatzen du. Nahiz eta lapurtera klasikoa edo literatur lapurtera deitzen ohi dena ez zen barietate guztiz estandardizatua izateraino iritsi, lapurtarrek idatzizko tradizio sendo bat zuten. Aldiz, ez dakigu tradizio horrek noraino eragin ziezaiekeen jende ez osoki alfabetatuei. Idazle guti alfabetatu haiek beren denborako kode ortografikoetan ukan zezaketen integrazio maila eta, oro har, haien idatz ohitzak ilunpeko gaiak dira, iturri aberatsagoak dituzten hizkuntzetan ere (Martineau 2007). Nederlanderazko ego-dokumentuen kari van der Wal-ek bere buruari pausatzen dizkion galderak pertinenteak dira hemen: "Did the previous linguistic variation largely vanish from usage? Did literate people in everyday life write according to the norms of the preferred variants?" (2007: 85). Ikusirik Le Dauphin gutuneriak lapurteraren historiaren zenbait lausogune (eta are hutsune) betetzen ahal duela, iraganeko hizkuntz aldakortasunaren azterketa eta soziolinguistika historikoaren hurbiltzea ahalbidetuz, azken galdera litzateke noraino den posible euskararen historiari behetik lotzea. 


\section{Erreferentziak}

Austin, Frances, 2000, "Letter Writing in a Cornish Community in the 1790s", in D. Barton \& N. Hall (arg.), Letter Writing as a Social Practice, John Benjamins, Amsterdam. 43-62.

—, 2004, "Heaving this importunity. The survival of opening formulas in letters in the eighteenth and nineteenth centuries", Historical Sociolinguistics and Sociohistorical Linguistics 4. <http://www.let.leidenuniv.nl/hsl_shl/heaving_this_importunity.htm> [azken kontsulta 2013/12/12].

Aurrekoetxea, Gotzon \& Videgain, Xarles, 2004, Bourciez-en "Recueil des idiomes de la région Gasconne" bildumako euskal testuak. <http://artxiker.ccsd.cnrs.fr/docs/00/08/05/48/ PDF/Haur_prodigoa_testuak.pdf> [azken kontsulta 2013/12/10].

Branca-Rosoff, Sonia, 1990, "Conventions d'écriture dans la correspondance des soldats", Mots 24, 21-37.

_ \& SCHNEIDER, Nathalie, 1994, L'écriture des citoyens: une analyse linguistique de l'écriture des peu-lettrés pendant la période révolutionnaire, Klincksieck, Paris.

Bruneton-Governatori, Arianne \& Moreux, Bernard, 1997, "Un modèle épistolaire populaire. Les lettres d'émigrés béarnais”, in D. Fabre (zuz.), Par écrit. Ethnologie des écritures quotidiennes, Maison des Sciences de l'Homme, Paris.

Dossena, Marina, 2012, "The study of correspondence. Theoretical and methodological issues", in Dossena \& del Lungo Camiciotti (arg.), 13-29.

— \& del Lungo Camiciotti, Gabriella (arg.), 2012, Letter Writing in Late Modern Europe, John Benjamins, Amsterdam.

ElsPass, Stephan, 2012a, "The Use of Private Letters and Diaries in Sociolinguistic Investigation", in Hernández-Campoy \& Conde-Silvestre (arg.). 156-169.

_ 2012b, "Between linguistic creativity and formulaic restriction. Cross-linguistic perspectives on nineteenth-century lower class writers' private letters", in Dossena \& del Lungo Camiciotti (arg.). 45-64.

Fitzmaurice, Susan M., 2002, The Familiar Letter in Early Modern English, John Benjamins, Amsterdam.

GrosperRin, Bernard, 1984, Les petites écoles sous l'Ancien Régime, Ouest-France, Rennes.

HÄCKER, Martina, 2010, "Cross-Language Transfer of Formulae: The case of English letters", $4^{\text {th }}$ Interdisciplinary Conference on Formulaic Language (FLaRN4), Universität Paderborn. $<$ http://kw.uni-paderborn.de/institute-einrichtungen/institut-fuer-anglistik-undamerikanistik/konferenzen/flarn/> [azken kontsulta 2013/12/10].

Hernández-Campoy, Juan M. \& Conde-Silvestre, Juan C. (arg.), 2012, The Handbook of Historical Sociolinguistics, Wiley-Blackwell, Oxford.

Hidiroglou, Patricia (arg.), 2003, Entre héritage et devenir. La construction de la famille juive. Études offertes à Joseph Mélèze-Modrzejewski, Publications de la Sorbonne, Paris.

Koch, Peter \& Oesterricher, Wulf, 1985, "Sprache der Nähe-Sprache der Distanz: Mündlichkeit und Schriftlichkeit im Spannungsfeld von Sprachtheorie und Sprachgeschichte", Romanistisches Jahrbuch 36, 15-43.

Laitinen, Lea \& Nordlund, Taru, 2012, "Performing identities and interaction through epistolary formulae", in Dossena \& del Lungo Camiciotti (arg.). 65-88.

Lamikiz, Xabier, 2010, Trade and Trust in the Eighteenth-Century Atlantic World: Spanish 
Merchants and Their Overseas Networks, Royal Historical Society - Boydell Press, Woodbridge.

McCafferty, Kevin \& Amador-Moreno, Carolina, 2012, "A Corpus of Irish English Correspondence (CORIECOR). A tool for studying the history and evolution of Irish English", in B. Migge \& M. Ní Chiosáin (arg.), New Perspectives on Irish English. 265288.

Martin, Charles, 1836, Complément des études sur la langue française: ou rhétorique-pratique des écoles primaires précédée d'un traité de métaphysique, Brunot Labbe, Paris.

Martineau, France, 2007, "Pratiques d'écriture des peu-lettrés en québécois ancien: morphologie verbale", in P. Larrivée (zuz.), Variation et stabilité du français. Des notions aux opérations. Mélanges de linguistique offerts au professeur Jean-Marcel Léard par ses collègues et amis, Peeters, Lovaina. 179-195.

Mitxelena, Koldo, 1964, Textos Arcaicos Vascos [ASJU-ren Gehigarriak 11], Gipuzkoako Foru Aldundia - UPV/EHU, Donostia.

MontGomery, Michael, 1995, "The Linguistic Value of Ulster Emigrant Letters", Ulster Folklife $41,26-41$.

Montillet, Jean-François, 1740, Reglement pour les petites ecoles du diocese d'Oleron, Imprimé par l'ordre de Monseigneur l'Illustrissime E Reverendissime Messire Jean-François de Montillet Evêque d'Oleron, Dupoux, Paue.

Moreux, Bernard, 1991, "Le Français écrit en Béarn au XVIIIe siècle", Revue de Pau et du Béarn $18,81-110$.

MujIKA, Jose A., 2002, Euskal ortografiaren hastapenak Iparraldeko literaturan, UPV/EHU, Bilbo.

Nevalainen, Terttu \& Raumolin-Brunberg, Helena, d.g., Corpora of Early English Correspondence. $<$ http://www.helsinki.fi/varieng/CoRD/corpora/CEEC/index.html> [azken kontsulta 2013/12/10].

Orpustan, Jean-Baptiste, 2010, "Correspondance basque à la fin du XVI siècle (1595-1598). 20 lettres de renseignements sur la politique de Henri IV et la fin des guerres contre la Ligue", Lapurdum 14, 137-162.

OyHarÇABAL, Beñat, 2001a, "Statut et évolution des lettres basques durant les XVII ${ }^{\text {ème }}$ et XVIII siècles", Lapurdum 6, 219-287.

_ 2001 b, "Zenbait gogoeta euskarak letra hizkuntza gisa izan duen bilakaeraz (XVIIXVIII. mendeak)", Litterae Vasconicae 8, 9-46.

Padilla-Moyano, Manuel, 2015, "A new view of Basque through eighteenth-century correspondence" in E-Torgersen, S. Hårstad, B. Moehlum \& V. Røne Pond (arg.), Language VARIATION, European Perspectives V, John Benjamins, Amsterdam.

PIKABEA, Josu, 1993, Lapurtera idatzia (XVII-XIX). Bilakaera baten urratsak, UPV/EHU, Donostia.

Rutten, Gijsbert \& van Der Wal, Marijke, 2012, "Functions of epistolary formulae in Dutch letters from the seventeenth and eighteenth centuries", Journal of Historical Pragmatics $13: 2,173-201$.

, 2013, "Epistolary Formulae and Writing Experience in Dutch Letters from the Seventeenth and Eighteenth Centuries", in van der Wal \& Rutten (arg.), Touching the Past. Studies in the Historical Sociolinguistics of Ego-documents, John Benjamins, Amsterdam. 45-65. 
Sarasola, Ibon, 1983, Contribución al estudio y edición de textos antiguos vascos [ASJU-ren Gehigarriak 11], Gipuzkoako Foru Aldundia - UPV/EHU, Donostia.

Satrústegui, José M., 1983, "Epistolario Vasco del siglo XVIII", ASJU 17, 3-24.

__, 1987, Euskal Testu Zaharrak (I), Euskaltzaindia, Iruñea.

SCHNEIDER, Edgar W., 2002, "Investigating variation and change in written documents", in P. Trudgill, J.K. Chambers \& N. Schilling-Estes (arg.), The Handbook of Language Variation and Change, Blackwell, Oxford. 67-96.

StaEs, Jacques, 1979-1992, "Lettres de soldats béarnais de la Révolution et du Premier Empire", Revue de Pau et de Béarn 7 (1979), 8 (1980), 9 (1981), 10 (1982), 11 (1983), 16 (1989) \& 19 (1992).

Urgell, Blanca, 2013, "Lehen euskara modernoa (1745-1875)", in J. Gorrochategui, I. Igartua \& J.A. Lakarra (arg.), Euskararen historia, Eusko Jaurlaritza, Vitoria-Gasteiz [moldiztegian].

VAN DER WAL, Marijke, 2007, "Eighteenth-century linguistic variation from the perspective of a Dutch diary and a collection of private letters", in S. Elspaß, N. Langer, J. Scharloth \& W. Vandenbussche (arg.), Germanic Language Histories 'from below' (1700-2000), Walter de Gruyter, Berlin / New York. 83-96.

_ (zuz.), Letters as Loot Project, Leiden Universiteit. <http://www.news.leiden.edu/news2013/letters-seized-from-dutch-ships-online.html> [azken kontsulta 2013/12/12].

— \& Rutten, Gijsbert, 2013, "The Practice of Letter Writing: Skills, Models, and Early Modern Dutch Manuals", Language and History 56:1, 18-32.

_ $\&$ Rutten, Gijsbert (arg.), 2013, Touching the Past. Studies in the Historical Sociolinguistics of the ego-documents, John Benjamins, Amsterdam.

— Rutten, Gijsbert \& Simons, Tanja, 2012, "Letters as loot. Confiscated letters filling major gaps in the history of Dutch", in Dossena \& del Lungo Camiciotti (arg.). 139-161.

Wagner, Esther M., Outhwaite, Ben \& Beinhoff, Bettina, 2013, "Scribes and language change", in Wagner, Outhwaite \& Beinhoff (arg.), Scribes as agents of language change, Mouton de Gruyter, Berlin.

Wray, Alison, 2005, Formulaic Language and the Lexicon, Cardiff University. 